\title{
A conjoint analysis of epilepsy and migraine through network- and-pathway-based method
}

\author{
Yi Shu ${ }^{1}$, Yuchen $\mathrm{Xu}^{2}$, Wenbiao Xiao ${ }^{2}$, Xianlian Deng ${ }^{2}$, Yi Zeng ${ }^{3}$, Ruijuan Chen ${ }^{3}$, Bo Xiao ${ }^{2}$, Hongyu Long ${ }^{2}$ \\ ${ }^{1}$ Department of Neurology, the Second Xiangya Hospital, Central South University, Changsha, China; ${ }^{2}$ Department of Neurology, the Xiangya \\ Hospital, Central South University, Changsha, China; ${ }^{3}$ Department of Geriatrics, the Second Xiangya Hospital, Central South University, Changsha, \\ China \\ Contributions: (I) Conception and design: Y Xu, H Long; (II) Administrative support: W Xiao, X Deng, B Xiao; (III) Provision of study materials \\ or patients: Y Xu, Y Zeng, R Chen; (IV) Collection and assembly of data: Y Xu; (V) Data analysis and interpretation: Y Shu, Y Xu, H Long; (VI) \\ Manuscript writing: All authors; (VII) Final approval of manuscript: All authors. \\ Correspondence to: Hongyu Long. Department of Neurology, the Xiangya Hospital, Central South University, No. 87 Xiangya Road, Changsha \\ 410008, China. Email: longhongyu@csu.edu.cn.
}

Background: Epilepsy and migraine are both considered as paroxysmal neurologic disorders. Previous
studies have reported some cases with comorbidity of these two diseases. As the underlying molecular
mechanism remains unclear, we performed a network-and-pathway-based method with candidate gene sets
of epilepsy and migraine to explore it.
Methods: Comparing the candidate genes between epilepsy and migraine, we identified 21 common
genes. Functional enrichment analysis indicated that epilepsy and migraine are dysfunctional in the similar
biological processes, such as glutamatergic transmissions, channel activities, and transporter activities.
We also explored many shared pathways between these two diseases such as neuroactive ligand-receptor
interaction.

Results: By combining systematical analysis and previous studies review, we finally identified six essential genes associated with the comorbidity of epilepsy and migraine.

Conclusions: This is the first time to address the common ground of epilepsy and migraine by a systematic biology method. The present study provides a novel way to explain the potential mechanisms of these two diseases and a new set of therapeutic targets.

Keywords: Epilepsy; migraine; network-and-pathway-based analysis

Submitted Dec 29, 2019. Accepted for publication Jul 28, 2020.

doi: 10.21037/apm-19-690

View this article at: http://dx.doi.org/10.21037/apm-19-690

\section{Introduction}

Migraine and epilepsy are ordinary paroxysmal neurological diseases (1). They both make frequent visits to outpatient clinic and emergency department and increase significant individual and social financial burdens (2). The migraine is defined as recurrent headache disorder manifesting in attacks lasting 4-72 hours; typical characteristics of the headache are unilateral location, pulsating quality, moderate or severe intensity, aggravation by routine physical activity and association with nausea and/or photophobia and phonophobia and it may be preceded by aura (3). Common migraine triggers include delayed or missed meals, menstruation, stress, weather changes, chocolate, soft cheeses, red wine, and artificial sweeteners, alcohol, and certain odors $(4,5)$. And it is suggested that patients write down a headache diary could help their physicians to identify and manage the migraine triggers (2). On the other hand, epilepsy is a symptom complex with multiple risk factors and a strong genetic predisposition rather than a condition with a single expression and cause. A detailed clinical history and a reliable eyewitness account of a 
seizure are the cornerstones of the diagnosis. Application of advanced brain imaging and electroencephalogram (EEG) devices can help to distinguish epilepsy from non-epileptic seizures (6).

As we know, in the pathogenesis, epilepsy is characterized by spontaneous, sudden, abnormal, excessive and rapid electrical discharges arising from cerebral neurons (7) while migraine is characterized by a complex and stereotypical, dysfunction of sensory processing (8). Interestingly, several studies have reported comorbidity of these two diseases $(9,10)$. Indeed, since the first report of their co-occurrences in the 19th century, more and more overlap of symptoms between these two disorders has been observed. First, both these disorders are manifested by periodic attacks and return to normality between crises $(11,12)$. Second, they can be induced by similar factors, such as exposure to a flashlight (13), psychological pressure $(14,15)$ and lack of sleep $(14,16)$. Third, they both show abnormal discharge in an EEG (17). Fourth, the presence of Aurae like visual hallucination and dizziness is frequently observed in both disorders $(18,19)$. Fifth, compared to the healthy population, both migraine and epilepsy have a higher prevalence of depression, anxiety and somatization (20,21). Moreover, a recent study reported that a remarkable family history of epilepsy increases the risks of migraine with aura (22). The evidence indicates these two diseases may share common pathogenesis and genetic susceptibilities. However, related studies are rare.

Therefore, it is indispensable to conduct a comprehensive and accurate exploration of the molecular mechanisms of the characteristic features of epilepsy and migraine. We searched the candidate genes manually to perform network and pathway-based analyses. As a result, we identified 21 overlapping genes and several common characteristics between epilepsy and migraine, including extracellular-glutamate-gated ion channel activity, glutamate binding, glutamate receptor activity, cation channel activity, substrate-specific transporter activity and ion transmembrane transporter activity. And among these genes, TNF, VEGFA, CACNA1A, ATP1A2, $S C N 1 A, P R R T 2$ are essential to the comorbidity between epilepsy and migraine. The current study may the underlying mechanisms of these two diseases and indicate the potential target of future prevention and therapy.

\section{Methods}

\section{Identification of epilepsy and migraine-related genes}

We retrieve the human genetic association studies deposited in PUBMED (http://www.ncbi.nlm.nih.gov/pubmed/). The search strategy is retrieve the researches related to epilepsy with the term (epilepsy[MeSH]) and (polymorphism $[\mathrm{MeSH}]$ or genotype $[\mathrm{MeSH}]$ or alleles $[\mathrm{MeSH}])$ ), and (migraine $[\mathrm{MeSH}]$ or hemicrania $[\mathrm{MeSH}]$ or cephalalgia $[\mathrm{MeSH}]$ ) and (polymorphism [MeSH] or genotype $[\mathrm{MeSH}]$ or alleles $[\mathrm{MeSH}])$ ) for migraine respectively. The inclusion criteria gene collection runs as follows: (I) at least 5 cases of patients with a specimen of the brain or peripheral blood. (II) All the candidate genes are validated by reliable biological experiments. (III) Candidate genes show a significant difference at the expression level. After reading the abstracts of these acquired publications, we selected the genes published to be associated with epilepsy and migraine. Then the whole reports of the selected publications were reviewed to ensure the conclusions were consistent with the content. The studies reporting nonsignificant or negative associations were excluded to lower the false-positive ratio. In a few studies, some several genes were cooperating to show significant effects on epilepsy and migraine, with each gene having a moderate impact; we also incorporated these genes into our list.

\section{Formation of protein-protein interaction (PPI) network}

The Search Tool for the Retrieval of Interacting Genes (STRING) (http://string-db.org/) is an online database which can offer a core integration of PPIs with a confidence score and generate a network (23). In the current study, the STRING online database was applied to analyze the PPIs of the candidate genes of epilepsy and migraine. Due to building the PPI network, only the genes with a combined protein interaction score $>0.5$ were calculated and analyzed. The PPI network was visualized, utilizing Cytoscape 3.4 (24).

\section{Functional enrichment analysis of genes related to epilepsy and migraine}

We operate DAVID and KEGG to detect the biological themes of the candidate genes related to epilepsy and migraine. DAVID, a web-based bioinformatic-mining platform, integrates information from multiple resources to analyse the biological processes, including identifying the overrepresented Gene Ontology (GO) terms (25). In the present study, only the enriched GO biological process terms with $\mathrm{P}$ value $<0.05$ meant significant and were reserved KEGG, a platform to calculate and analyze the 
enriched biological pathways in the candidate genes, was used synchronously (26). Enriched pathways with $\mathrm{P}$ value $<0.05$ were significantly kept.

We also analysed the interrelations of the enriched pathways. The Fisher's Exact Test with the formula above was used to calculate the overlap between two pathways.

$$
P=1-\sum_{k=0}^{x} \frac{\left(\begin{array}{c}
m \\
k
\end{array}\right)\left(\begin{array}{c}
N-m \\
n-k
\end{array}\right)}{\left(\begin{array}{c}
N \\
n
\end{array}\right)}
$$

Only pathways with $\mathrm{P}$ value $<0.05$ were considered for crosstalk analysis. Pathways with less than or equal to three candidate genes were discarded since such pathways represent few or biased connections with others. Furthermore, the pathway pairs having the number of common candidate genes less than two were removed.

\section{Results}

\section{Identification of candidate genes related to epilepsy and migraine}

Discovery of genes linked with epilepsy were completed through searching the published genetic studies associated with epilepsy in PubMed. Only the publications reporting gene(s) significantly associated with the disease were gathered, and those reporting a negative or nonsignificant association were excluded. Altogether, from 545 studies, we collected 171 genes be related to epilepsy (Table S1). Similarly, we collected 70 candidate genes be associated with migraine from 172 studies (Table S2). Comparing two gene lists, we found 21 genes shared by these two disease. These genes are associated with oxidative stress, ion channels and energy metabolism refer to previous studies, partly indicating the complication of the pathogenesis of epilepsy and migraine. The overlapping genes are shown in Table 1.

\section{Construction and analysis of the PPI networks}

By mapping the epilepsy-related genes into STRING database, we constructed a PPI network with 156 nodes (epilepsy-related genes) and 1,281 edges (interactions). As for migraine-related genes, the network included 55 nodes (migraine-related genes) and 139 edges (interactions). The plot of the networks is in the Figures S1,S2. The top 10 ranked hub proteins with high degree in the networks of epilepsy and migraine were shown in Table 2.

\section{Biological functional enrichment analysis of candidate genes}

A more detailed biological function pattern of two gene sets was revealed through functional enrichment analysis (Table S3,S4). The GO terms significantly enriched in the epilepsy-related genes and migraine-related genes are partially similar, including those associated with glutamatergic transmission (e.g., glutamate receptor activity, extracellular-glutamate-gated ion channel activity, glutamate binding) and channel activities (e.g., gated channel activity, extracellular ligand-gated ion channel activity, cation channel activity), transporter activities (e.g., substrate-specific transporter activity, metal ion transmembrane transporter activity). These results indicated that complicated connections existed between these two diseases. In addition, theses selected genes were relatively credible for following bioinformatics analysis.

Identifying the biochemical pathways enriched in the candidate genes may provide valuable evidence for our understanding of the molecular mechanisms underlying epilepsy and migraine. We searched for enriched pathways in the two sets of candidate genes using KEGG. As a result, we explore 35 significantly enriched pathways for migraine (Table S5) and 129 significantly enriched pathways for epilepsy (Table S6). Interestingly, we found numerous pathways shared by epilepsy and migraine (Table 3).

\section{Crosstalk among significantly enriched pathways in epilepsy and migraine}

Detecting the significantly enriched pathways may provide valuable evidence for understanding their interactions, we dealed a pathway crosstalk calculation with the 129 significantly enriched pathways in epilepsy-related genes and 35 significantly enriched pathways in migraine-related genes. Here we assumed that crosstalk existed a pathway pair if they shared a percentage of candidate genes. A plugin of Cytoscape named ClueGO (27) was used for visualization. The results are shown in Figures 1,2.

\section{Discussion}

During the past decades, considerable studies have been performed on epilepsy and migraine separately. Nowadays 
Table 1 Overlapping genes between epilepsy and migraine

\begin{tabular}{|c|c|c|}
\hline Gene & ID & Description \\
\hline ATP1A2 & 477 & ATPase $\mathrm{Na}+/ \mathrm{K}+$ transporting subunit alpha 2 \\
\hline CACNA1A & 773 & Calcium voltage-gated channel subunit alpha1 $\mathrm{A}$ \\
\hline GABRA3 & 2556 & Gamma-aminobutyric acid type A receptor alpha3 subunit \\
\hline GRIA1 & 2890 & Glutamate ionotropic receptor AMPA type subunit 1 \\
\hline GRM7 & 2917 & Glutamate metabotropic receptor 7 \\
\hline HTR1B & 3351 & 5-hydroxytryptamine receptor $1 \mathrm{~B}$ \\
\hline KCNN3 & 3782 & Potassium calcium-activated channel subfamily $\mathrm{N}$ member 3 \\
\hline SCN1A & 6323 & Sodium voltage-gated channel alpha subunit 1 \\
\hline CCL2 & 6347 & C-C motif chemokine ligand 2 \\
\hline SLC6A4 & 6532 & Solute carrier family 6 member 4 \\
\hline TGFB1 & 7040 & Transforming growth factor beta 1 \\
\hline TGFBR2 & 7048 & Transforming growth factor beta receptor 2 \\
\hline TNF & 7124 & Tumor necrosis factor \\
\hline VDR & 7421 & Vitamin D receptor \\
\hline VEGFA & 7422 & Vascular endothelial growth factor $A$ \\
\hline
\end{tabular}

numerous genes/proteins have been identified to associated with these two disorders, however, it remains unclear that a comprehensive understanding of the biological mechanisms related to pathogenesis of these two diseases especially the comorbidity between them. So, it is essential to reveal the underlying molecular processes involved in the epilepsy and migraine by collecting the genes related to these two diseases and systematically exploring the interaction of candidate genes. In the present study, we found several shared characteristics of these two diseases and delineated possible biochemical processes contributing to their comorbidity through network and pathway-based method.

In our study, we selected 171 genes reported to be associated with epilepsy and 70 candidate genes related to migraine. Comparing two gene lists, we found 21 genes shared by these two diseases and former studies have reported that some of them play certain roles in both epilepsy and migraine (e.g., $C A C N A 1 A, A T P 1 A 2$, $S C N 1 A, P R R T 2)$. The CACNA1A gene encodes for the $\mathrm{Ca} 2.1 \alpha 1$ subunit. It is closely linked with synaptic function of cortical interneurons and function of cortical GABA neurotransmitter $(28,29)$, which ultimately leads to epilepsy and migraine. ATP1A2 codes for the $\alpha 2$ subunit of $\mathrm{Na}+/$ $\mathrm{K}+$ ATPase. The dysfunction of $\mathrm{Na}+\mathrm{K}+$ ATPase damages the $\mathrm{K}+$ gradient and impairs glutamate clearance, which could participant in the pathogenesis of migraine and epilepsy by depressing the cortical spreading (30). The $S C N 1 A$ gene encodes for Nav1.1. The dysfunction of Nav1.1 could prolong current duration and increase neuron excitability, which lead to seizures and familial hemiplegic migraine (31). The mutation of PRRT2 gene impairs SNAP25 function, which alters CaV2.1 activity, enhances neuronal hyper-excitability, and results in epilepsy and hemiplegic migraine (32). Importantly, other unreported 
Table 2 The top 10 genes with high node degree in the PPI network of epilepsy and migraine

\begin{tabular}{|c|c|}
\hline Epilepsy genes & Degree \\
\hline TP53 & 67 \\
\hline$A K T 1$ & 63 \\
\hline TNF & 60 \\
\hline IL6 & 60 \\
\hline VEGFA & 56 \\
\hline BCL2 & 52 \\
\hline MAPKЗ & 52 \\
\hline CASP3 & 51 \\
\hline MAPK1 & 51 \\
\hline$A P P$ & 50 \\
\hline TNF & 21 \\
\hline VEGFA & 18 \\
\hline TGFB1 & 17 \\
\hline NOS3 & 15 \\
\hline CCL2 & 13 \\
\hline$A C E$ & 12 \\
\hline$A P O E$ & 11 \\
\hline CCR2 & 9 \\
\hline NOS2 & 9 \\
\hline ESR1 & 9 \\
\hline
\end{tabular}

genes are likely to contribute to epilepsy and migraine through undefined but similar molecular mechanisms. It is worth exploring them in the future.

By mapping the candidate genes into STRING database, we constructed the PPI networks of epilepsy and migraine. Interestingly, we found that several genes serve as hub gene in both networks, such as TNF and VEGFA. In the past decades, these two genes have been reported to participate in many neurological disorders. TNF plays a vital role in the microglia and astrocyte activation which are the initial stages of inflammatory responses in the central nervous system $(\mathrm{CNS})(33,34)$. Several studies indicated that seizures induce the brain-derived TNF expression in animal models (35-37). Balosso et al. injected murine-recombinant TNF into the hippocampus of mice and reported a potent prevention of seizures (38). Teocchi et al. (39) reported a notable TNF upregulation in the patients of temporal lobe epilepsy (TLE) and suggested chronic inflammation could be crucial to refractory TLE (40). Moreover, Chen et al. reported that some polymorphisms of TNF increase genetic susceptibility to migraine (41). Therefore, we assume that epilepsy and migraine may have similar inflammatory process via TNF signal pathway. Further experiments are needed to verify this point. VEGF is a crucial protein in the angiogenesis and it also participates in neurogenesis (42). And VEGF signaling could take a part in astrocytes activation and astrocyte-related inflammatory reactions (43). Besides, in a case-control study, patients with migraine showed significantly increased levels of VEGF than the control group, which indicates that VEGF is close associated with migraine (44).

Biological function enrichment analysis of candidate genes detected the detailed biological processes. The current GO enrichment analysis demonstrated that both epilepsy-related genes and migraine-related genes participated in glutamatergic transmissions (e.g., glutamate receptor activity, extracellular-glutamate-gated ion channel activity, glutamate binding) and channel activities (e.g., gated channel activity, extracellular ligand-gated ion channel activity, cation channel activity), transporter activities (e.g., substrate-specific transporter activity, metal ion transmembrane transporter activity). This result revealed that epilepsy and migraine shared some similar biological processes in their pathogenesis.

Pathway analysis revealed many common pathways between epilepsy and migraine. Among these common pathways, some are reported to be associated with specific diseases by previous studies such as dopaminergic synapse, serotonergic synapse and estrogen signaling pathway. Dopamine and serotonin are common neurotransmitter with excitatory and inhibitory functions. Once these neurotransmitters interact with the specific receptors, thus triggering various important signaling pathways in the CNS, and then finally regulate a series of physiological processes $(45,46)$. The former studies indicated that they marginally participate in the synaptic plasticity $(47,48)$. Central dopaminergic synapse was considered as a malfunctioning regulatory circuit, insufficient release of feedback control might increase seizure susceptibility (49). Migraine can be affected by fluctuating estrogen levels and high estrogen levels can trigger migraine aura (50,51). Furthermore, down-regulation of serotonergic and GABAergic systems could inhibit the estrogen product, which increases the risk of migraine. Interestingly, some women with 
Table 3 Pathways shared by epilepsy and migraine

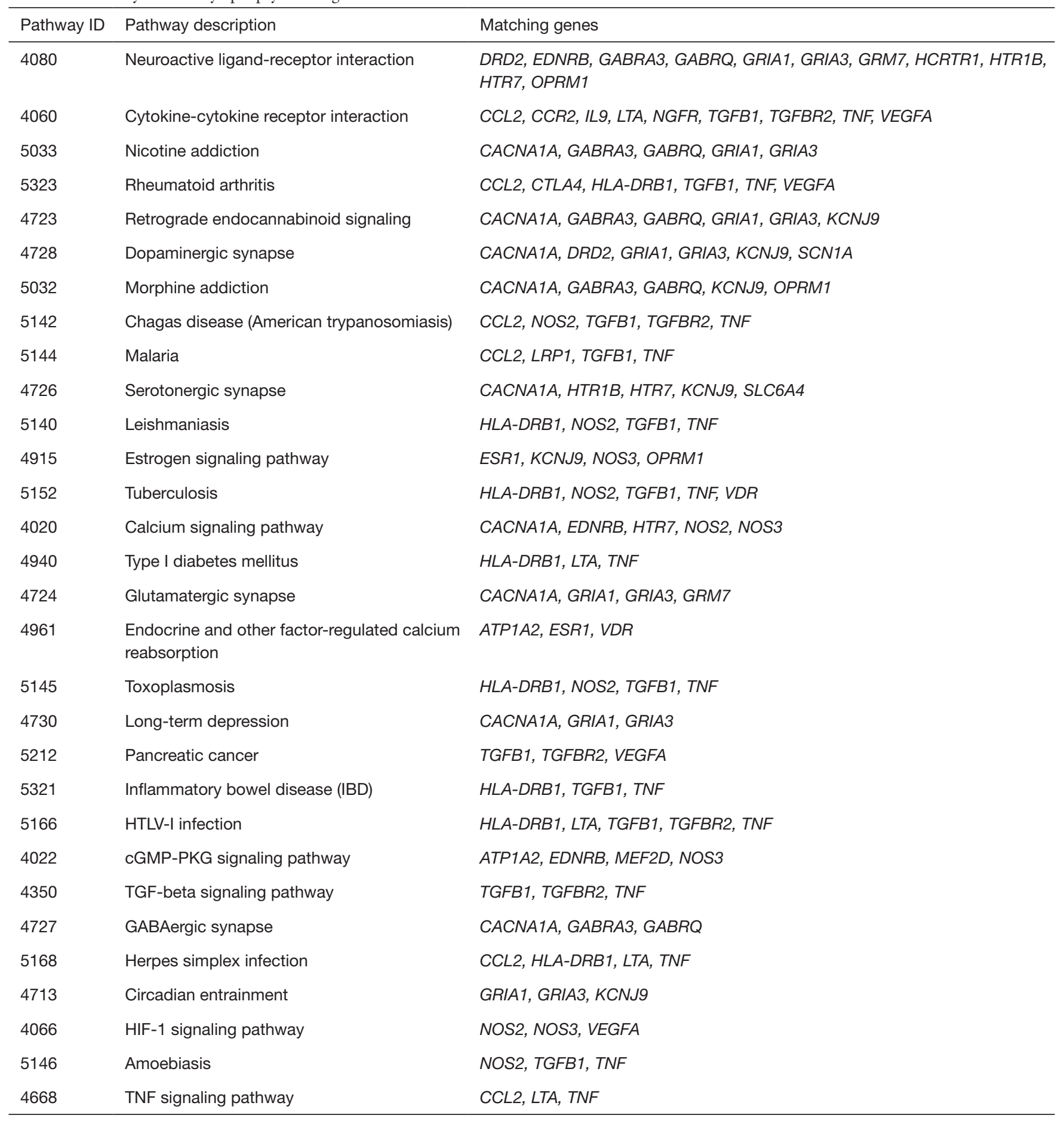




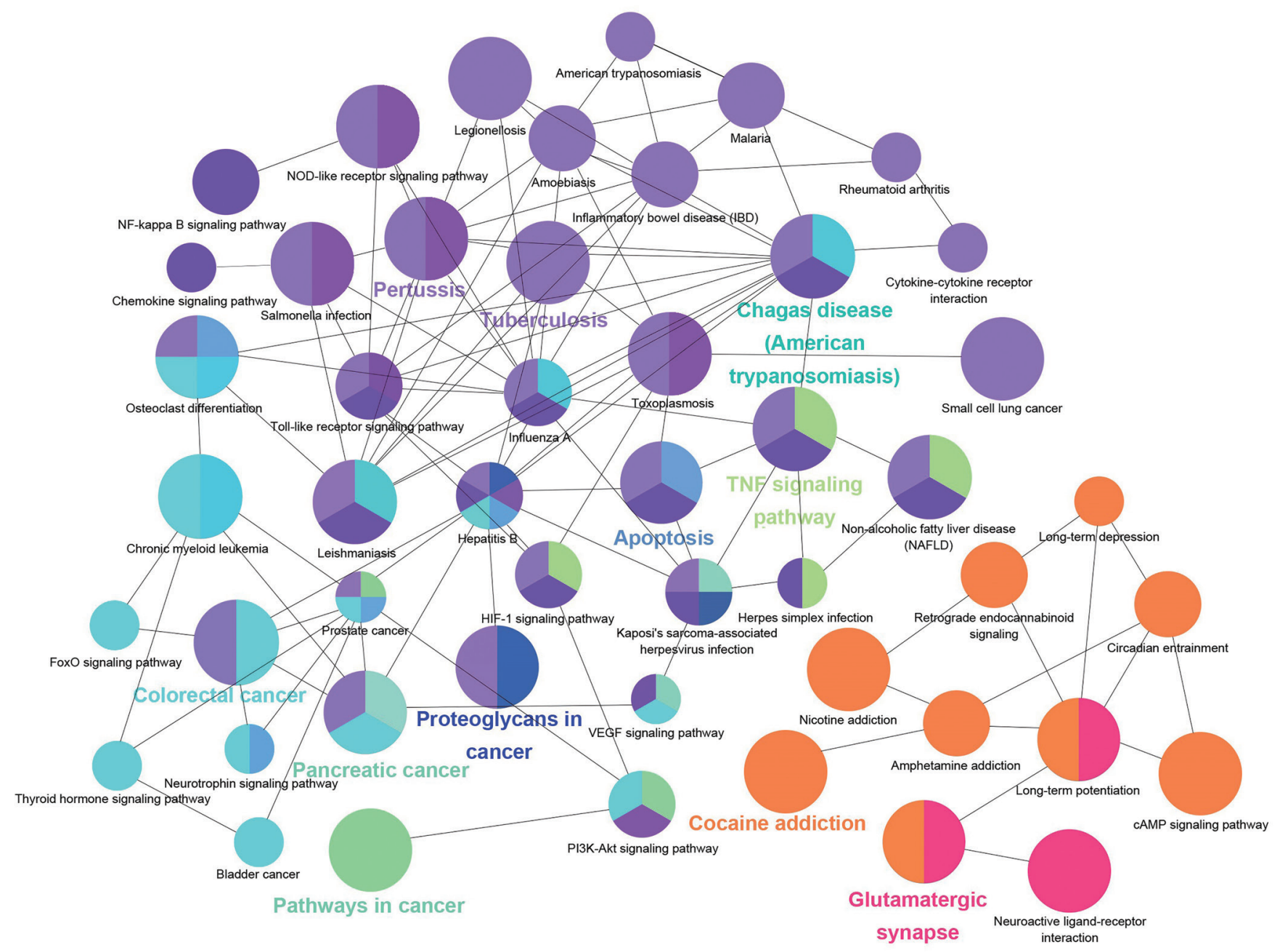

Figure 1 Crosstalk of pathway enriched in epilepsy-related genes.

epilepsy showed particular vulnerability to seizures during menstruation and ovulation, which is named catamenial epilepsy $(52,53)$. This phenomenon indicates that epilepsy is also partially influenced by estrogen level. Therefore, estrogen level is very possible to perform as a common trigger of both epilepsy and migraine. In addition, a study of the human partial epilepsy indicated that glutamatergic synaptic transmission increases the hyper-excitability of hippocampal CA1 pyramidal neurons and contribute to seizure (54). Yet, former researches have reported few shared pathways between epilepsy and migraine.

Significantly, pathway crosstalk analysis help us further understanding the interaction between those enriched pathways. We found that pathways in these two diseases can be generally separated into two modules. One includes those pathways explicitly involved in neuron of CNS according to previous studies (e.g., dopaminergic synapse, retrograde endocannabinoid signaling, long-term depression, nicotine addiction). The other is the pathways mainly involved in inflammatory response or some inflammatory disorders (e.g., inflammatory bowel disease, TNF signaling pathway, rheumatoid arthritis). According to the results we further speculate inflammatory response is crucial in epilepsy and migraine.

Through systematic analysis and previous studies review, we considered 6 genes (TNF, VEGFA, CACNA1A, ATP1A2, $S C N 1 A, P R R T 2)$ as important to the comorbidity between epilepsy and migraine. We also predict genes that interact with these 6 essential genes via GeneMania, which may participant in the occurence and development of epilepsy 


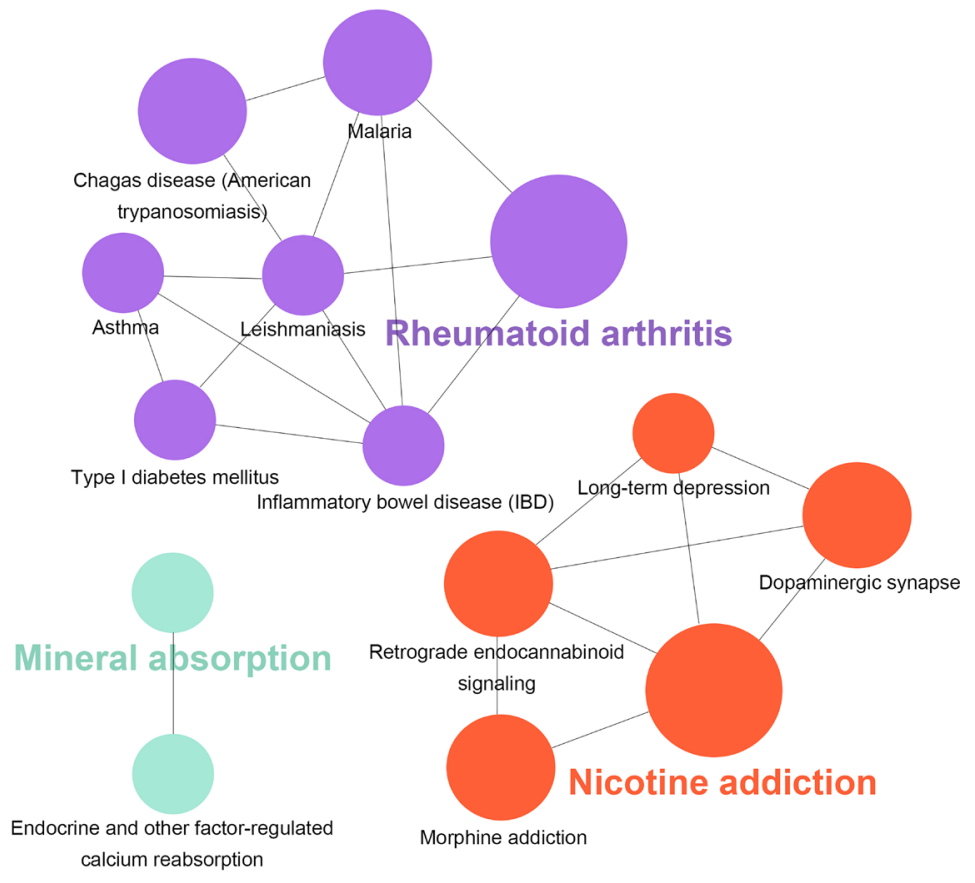

Figure 2 Crosstalk of pathway enriched in migraine-related genes.

and migraine (55). Hopefully, these potential candidate genes are on a list for further exploration. The results are shown in Figure 3.

Still, in this study these analysis results of pathways and networks depend entirely on genes in the published data purported to be linked to epilepsy and migraine is a limit. Given that the process of candidate genes identifications is sustaining, the relevant analysis and results should update along with time.

Nowadays, novel drugs for epilepsy and migraine are still urgently needed. The concept of "disease-modifying drugs in epilepsy" is coming up and the mTOR inhibitor Everolimus seems to have a similar but slightly delayed antiseizure efficacy in tuberous sclerosis complex disease associated seizures (56). The gut microbiome could give extra assistance to improve the efficacy of the ketogenic diet (57). For migraine, due to advancement in the understanding of migraine pathophysiological mechanisms and identification of hopeful potentially meaningful targets have resulted in a multitude of emerging acute and preventive treatments. The most promising acute therapies which target the Calcitonin-Gene-Related Peptide (CGRP) receptor and ligand and the 5 hydroxytryptamine $(5-\mathrm{HT})$ $1 \mathrm{~F}$ receptor are two new family of drugs: the Gepants and the Ditans. As preventive treatments, the anti-CGRP monoclonal antibodies like Erenumab and Fremanezumab is a major milestone since the approval of triptans (58). Surgery is essential for refractory epilepsy treatment. Traditional craniotomy could bring damage to surrounding brain tissue and worsen postsurgical neurological and neuropsychological outcome (59). An abolition of the local epileptogenic zone with non- or less invasive techniques such as stereotactic radiosurgery, radiofrequency thermocoagulation, and laser interstitial thermal therapy, could reduce mentioned risks and have been shown to lead to a favourable seizure outcome in $50-60 \%$ of people with drug-resistant focal epilepsy (6). However, the efficacy and safety are currently under investigation with MRguided ultrasound (60). Furthermore, whatever in epilepsy or migraine, neuromodulatory approaches are alternative treatment strategies when patients are unwilling to accept or tolerate possible drug-induced adverse effect (61).

In summary, we collected some genes existed in epilepsy and migraine from literatures deposited in PubMed and performed a comprehensive and systematic analysis in this study. Then, we integrated the information from GO, KEGG and pathway crosstalk analysis platforms and figured out several biological processes and biochemical pathways related to neuroactive ligand-receptor interaction, dopaminergic synapse and glutamatergic synapse were 


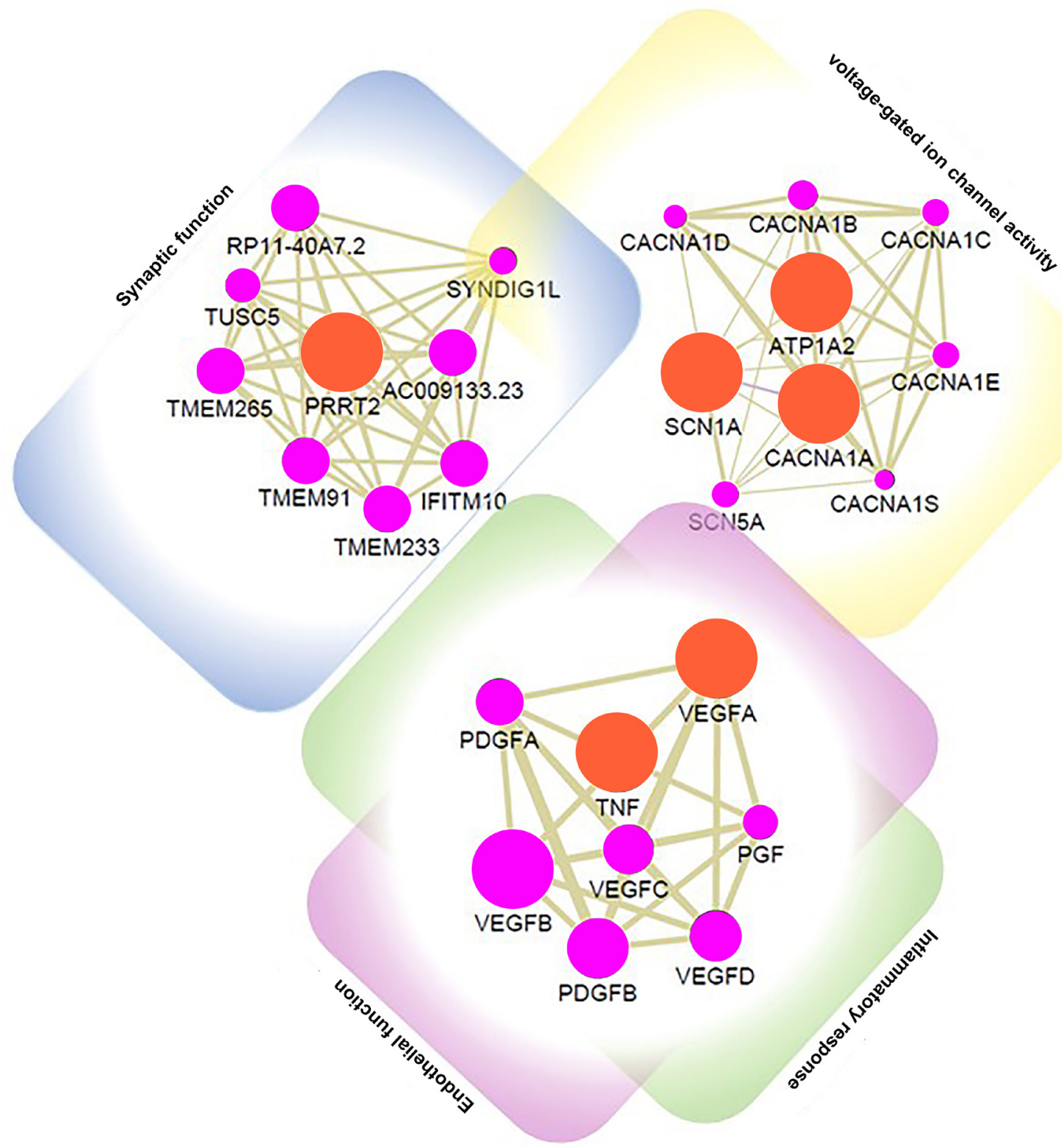

Figure 3 Predition of genes interact with TNF, VEGFA, CACNA1A, ATP1A2, SCN1A, PRRT2 and the potential biological processes involved.

enriched in both epilepsy and migraine genes and revealed the interrelations among these significant pathways. Meanwhile, we highlighted 6 essential genes: TNF, VEGFA, CACNA1A, ATP1A2, SCN1A, PRRT2, which may play an important role in both epilepsy and migraine. Such a network-and-pathway-based method will not only help us to comprehensively understand the contribution of genetic factors and their interaction to the combid mechanisms of epilepsy and migraine but will also provide a way to find potential therapeutic targets.

\section{Acknowledgments}

We would like to thank $\mathrm{PhD}$. Zhaohui Luo for revising and editing the manuscript.

Funding: The National Natural Science Foundation of China provided financial support in the form of direct funding (No. 81601141; 81974206) and the Science and 
Technology Department Funds of Hunan Province Key Project (No. 2018JJ3822; No. 2019JJ50884).

\section{Footnote}

Data Sharing Statement: Available at http://dx.doi. org/10.21037/apm-19-690

Conflicts of Interest: All authors have completed the ICMJE uniform disclosure form (available at http://dx.doi. org/10.21037/apm-19-690). YS reports grants from The National Natural Science Foundation of China, the Science and Technology Department Funds of Hunan Province Key Project during the conduct of the study. Dr. Bo Xiao reports grants from The National Natural Science Foundation of China during the conduct of the study. HL reports grants from the Science and Technology Department Funds of Hunan Province Key Project during the conduct of the study. The other authors have no conflicts of interest to declare.

Ethical Statement: The authors are accountable for all aspects of the work in ensuring that questions related to the accuracy or integrity of any part of the work are appropriately investigated and resolved.

Open Access Statement: This is an Open Access article distributed in accordance with the Creative Commons Attribution-NonCommercial-NoDerivs 4.0 International License (CC BY-NC-ND 4.0), which permits the noncommercial replication and distribution of the article with the strict proviso that no changes or edits are made and the original work is properly cited (including links to both the formal publication through the relevant DOI and the license). See: https://creativecommons.org/licenses/by-nc-nd/4.0/.

\section{References}

1. Guekht A. Epilepsy, Comorbidities and Treatments. Curr Pharm Des 2017;23:5702-26.

2. Ha H, Gonzalez A. Migraine Headache Prophylaxis. Am Fam Physician 2019;99:17-24.

3. Headache Classification Committee of the International Headache Society (IHS). The International Classification of Headache Disorders, 3rd edition. Cephalalgia 2018;38:1-211.

4. Starling AJ, Dodick DW. Best practices for patients with chronic migraine: burden, diagnosis, and management in primary care. Mayo Clin Proc 2015;90:408-14.

5. Kelman L. The triggers or precipitants of the acute migraine attack. Cephalalgia 2007;27:394-402.

6. Thijs RD, Surges R, O'Brien TJ, Sander JW. Epilepsy in adults. Lancet 2019;393:689-701.

7. Sander JW. The epidemiology of epilepsy revisited. Curr Opin Neurol 2003;16:165-70.

8. Sprenger T, Goadsby PJ. Migraine pathogenesis and state of pharmacological treatment options. BMC Med 2009;7:71.

9. Sowell MK, Youssef PE. The Comorbidity of Migraine and Epilepsy in Children and Adolescents. Semin Pediatr Neurol 2016;23:83-91.

10. Derakhshan I. Killing two birds with one stone: successful opioid monotherapy in intractable migraine-triggered epilepsy, a case series. Ther Adv Chronic Dis 2017;8:12-5.

11. Chen SC. Epilepsy and migraine: The dopamine hypotheses. Med Hypotheses 2006;66:466-72.

12. Srinivasa R, Kumar R. Migraine variants and beyond. J Assoc Physicians India 2010;58 Suppl:14-7.

13. Akben SB, Subasi A, Tuncel D. Analysis of EEG signals under flash stimulation for migraine and epileptic patients. J Med Syst 2011;35:437-43.

14. Schoonman GG, Evers DJ, Ballieux BE, et al. Is stress a trigger factor for migraine? Psychoneuroendocrinology 2007;32:532-8.

15. Sajatovic M, Tatsuoka C, Welter E, et al. Correlates of quality of life among individuals with epilepsy enrolled in self-management research: From the US Centers for Disease Control and Prevention Managing Epilepsy Well Network. Epilepsy Behav 2017;69:177-80.

16. Schmitt B. Sleep and epilepsy syndromes. Neuropediatrics 2015;46:171-80.

17. Cianchetti C, Avanzini G, Dainese F, et al. The complex interrelations between two paroxysmal disorders: headache and epilepsy. Neurol Sci 2017;38:941-8.

18. Barré M, Hamelin S, Minotti L, et al. Epileptic seizure and migraine visual aura: revisiting migralepsy. Rev Neurol (Paris) 2008;164:246-52.

19. Tsuji S. Migraine and epilepsy. Rinsho Shinkeigaku 2014;54:1003-5.

20. Hilty DM, Bourgeois JA, Chang CH, et al. Somatization Disorder. Curr Treat Options Neurol 2001;3:305-20.

21. Kanner AM, Scharfman H, Jette N, et al. Epilepsy as a Network Disorder (1): What can we learn from other network disorders such as autistic spectrum disorder and mood disorders? Epilepsy Behav 2017;77:106-13. 
22. Winawer MR, Connors R; EPGP Investigators. Evidence for a shared genetic susceptibility to migraine and epilepsy. Epilepsia 2013;54:288-95.

23. Szklarczyk D, Morris JH, Cook H, et al. The STRING database in 2017: quality-controlled protein-protein association networks, made broadly accessible. Nucleic Acids Res 2017;45:D362-8.

24. Demchak B, Hull T, Reich M, et al. Cytoscape: the network visualization tool for GenomeSpace workflows. F1000Res 2014;3:151.

25. Huang da W, Sherman BT, Lempicki RA. Systematic and integrative analysis of large gene lists using DAVID bioinformatics resources. Nat Protoc 2009;4:44-57.

26. Kanehisa M, Goto S. KEGG: kyoto encyclopedia of genes and genomes. Nucleic Acids Res 2000;28:27-30.

27. Bindea G, Mlecnik B, Hackl H, et al. ClueGO: a Cytoscape plug-in to decipher functionally grouped gene ontology and pathway annotation networks. Bioinformatics 2009;25:1091-3.

28. Kono S, Terada T, Ouchi Y, et al. An altered GABA-A receptor function in spinocerebellar ataxia type 6 and familial hemiplegic migraine type 1 associated with the CACNA1A gene mutation. BBA Clin 2014;2:56-61.

29. Epi4K Consortium. De Novo Mutations in SLC1A2 and CACNA1A Are Important Causes of Epileptic Encephalopathies. Am J Hum Genet 2016;99:287-98.

30. Murphy OC, Merwick A, O Mahony O, et al. Familial Hemiplegic Migraine With Asymmetric Encephalopathy Secondary to ATP1A2 Mutation: A Case Series. J Clin Neurophysiol 2018;35:e3-e7.

31. Claes L, Del-Favero J, Ceulemans B, et al. De novo mutations in the sodium-channel gene SCN1A cause severe myoclonic epilepsy of infancy. Am J Hum Genet 2001;68:1327-32.

32. Cohen-Kutner M, Nachmanni D, Atlas D. CaV2.1 (P/ $\mathrm{Q}$ channel) interaction with synaptic proteins is essential for depolarization-evoked release. Channels (Austin) 2010;4:266-77.

33. Madsen PM, Motti D, Karmally S, et al. Oligodendroglial TNFR2 Mediates Membrane TNF-Dependent Repair in Experimental Autoimmune Encephalomyelitis by Promoting Oligodendrocyte Differentiation and Remyelination. J Neurosci 2016;36:5128-43.

34. Ohgidani M, Kato TA, Hosoi M, et al. Fibromyalgia and microglial TNF- $\alpha$ : Translational research using human blood induced microglia-like cells. Sci Rep 2017;7:11882.

35. Vezzani A, Moneta D, Richichi C, et al. Functional role of inflammatory cytokines and antiinflammatory molecules in seizures and epileptogenesis. Epilepsia 2002;43 Suppl 5:30-5.

36. Li G, Bauer S, Nowak M, et al. Cytokines and epilepsy. Seizure 2011;20:249-56.

37. Ravizza T, Balosso S, Vezzani A. Inflammation and prevention of epileptogenesis. Neurosci Lett 2011;497:223-30.

38. Balosso S, Ravizza T, Perego C, et al. Tumor necrosis factor-alpha inhibits seizures in mice via p75 receptors. Ann Neurol 2005;57:804-12.

39. Teocchi MA, Ferreira AÉ, da Luz de Oliveira EP, et al. Hippocampal gene expression dysregulation of Klotho, nuclear factor kappa B and tumor necrosis factor in temporal lobe epilepsy patients. J Neuroinflammation 2013;10:53.

40. Teocchi MA, D'Souza-Li L. Apoptosis through Death Receptors in Temporal Lobe EpilepsyAssociated Hippocampal Sclerosis. Mediators Inflamm 2016;2016:8290562.

41. Chen M, Tang W, Hou L, et al. Tumor Necrosis Factor (TNF) -308G>A, Nitric Oxide Synthase 3 (NOS3) +894G>T Polymorphisms and Migraine Risk: A MetaAnalysis. PLoS One 2015;10:e129372.

42. Houlihan SL, Lanctot AA, Guo Y, et al. Upregulation of neurovascular communication through filamin abrogation promotes ectopic periventricular neurogenesis. Elife 2016;5:e17823.

43. Boer K, Troost D, Spliet WG, et al. Cellular distribution of vascular endothelial growth factor A (VEGFA) and B (VEGFB) and VEGF receptors 1 and 2 in focal cortical dysplasia type IIB. Acta Neuropathol 2008;115:683-96.

44. Rodríguez-Osorio X, Sobrino T, Brea D, et al. Endothelial progenitor cells: a new key for endothelial dysfunction in migraine. Neurology 2012;79:474-9.

45. Todd RD. Neural development is regulated by classical neurotransmitters: dopamine D2 receptor stimulation enhances neurite outgrowth. Biol Psychiatry 1992;31:794-807.

46. Xu X, Zheng C, An L, et al. Effects of Dopamine and Serotonin Systems on Modulating Neural Oscillations in Hippocampus-Prefrontal Cortex Pathway in Rats. Brain Topogr 2016;29:539-51.

47. Suzuki T, Miura M, Nishimura K, et al. Dopaminedependent synaptic plasticity in the striatal cholinergic interneurons. J Neurosci 2001;21:6492-501.

48. Rylander D, Bagetta V, Pendolino V, et al. Region-specific restoration of striatal synaptic plasticity by dopamine grafts in experimental parkinsonism. Proc Natl Acad Sci U S A 
2013;110:E4375-84.

49. Lamprecht F. Epilepsy and schizophrenia: a neurochemical bridge. J Neural Transm 1977;40:159-70.

50. Warnock JK, Cohen LJ, Blumenthal H, et al. HormoneRelated Migraine Headaches and Mood Disorders: Treatment with Estrogen Stabilization. Pharmacotherapy 2017;37:120-8.

51. MacGregor EA. Migraine, menopause and hormone replacement therapy. Post Reprod Health 2018;24:11-18.

52. Reddy DS. Catamenial Epilepsy: Discovery of an Extrasynaptic Molecular Mechanism for Targeted Therapy. Front Cell Neurosci 2016;10:101.

53. Khishfe BF. Catamenial Epilepsy: The Menstrual Cycle as a Clue to Predict Future Refractory Seizures. J Emerg Med 2017;52:235-7.

54. Anderson MP. Arrested glutamatergic synapse development in human partial epilepsy. Epilepsy Curr 2010;10:153-8.

55. Montojo J, Zuberi K, Rodriguez H, et al. GeneMANIA: Fast gene network construction and function prediction for Cytoscape. F1000Res 2014;3:153.

Cite this article as: Shu Y, Xu Y, Xiao W, Deng X, Zeng Y, Chen R, Xiao B, Long H. A conjoint analysis of epilepsy and migraine through network-and-pathway-based method. Ann Palliat Med 2020;9(5):2642-2653. doi: 10.21037/apm-19-690
56. French JA, Lawson JA, Yapici Z, et al. Adjunctive everolimus therapy for treatment-resistant focal-onset seizures associated with tuberous sclerosis (EXIST-3): a phase 3, randomised, doubleblind, placebo-controlled study. Lancet 2016;388:2153-63.

57. Olson CA, Vuong HE, Yano JM, et al. The gut microbiota mediates the anti-seizure effects of the ketogenic diet. Cell 2018;174:497.

58. Lambru G, Andreou AP, Guglielmetti M, et al. Emerging drugs for migraine treatment: an update. Expert Opin Emerg Drugs 2018;23:301-18.

59. Helmstaedter C. Cognitive outcomes of different surgical approaches in temporal lobe epilepsy. Epileptic Disord 2013;15:221-39.

60. Krishna V, Sammartino F, Rezai A. A review of the current therapies, challenges, and future directions of transcranial focused ultrasound technology: advances in diagnosis and treatment. JAMA Neurol 2018;75:246-54.

61. Goadsby PJ, Holland PR. Migraine Therapy: Current Approaches and New Horizons. Neurotherapeutics 2018;15:271-3. 


\begin{tabular}{|c|c|c|c|}
\hline No. & Gene & Gene ID & Reference ${ }^{*}$ \\
\hline 1 & ADARB2 & 105 & 3604878 \\
\hline 2 & ApoE & 348 & 4534059 \\
\hline 3 & ATP1A2 & 477 & 2034370,4706665 \\
\hline 4 & CACNA1A & 773 & 1377706 \\
\hline 5 & CASQ 1 & 844 & 2034370 \\
\hline 6 & CTLA-4 & 1493 & 3452029 \\
\hline 7 & CYP19A1 & 1588 & 3325278 \\
\hline 8 & $A C E$ & 1636 & 2644823 \\
\hline 9 & DRD2 & 1813 & 3476140 \\
\hline 10 & EDNRB & 1910 & 2753702 \\
\hline 11 & ESR1 & 2099 & 4616512 \\
\hline 12 & FMR1 & 2332 & 4991825 \\
\hline 13 & GABRA3 & 2556 & 3764027,1196377 \\
\hline 14 & GC Globulin & 2638 & 4141767 \\
\hline 15 & GRIA1 & 2890 & 4723374 \\
\hline 16 & GRIA3 & 2892 & 4723374 \\
\hline 17 & GRM7 & 2917 & 3604878 \\
\hline 18 & HCRTR1 & 3061 & 3072499 \\
\hline 19 & HLA-DRB1 & 3123 & 3452004 \\
\hline 20 & HTR1B & 3351 & 3476140 \\
\hline 21 & HTR7 & 3363 & 3604878 \\
\hline 22 & IL9 & 3578 & 2704575 \\
\hline 23 & KCN J9 & 3765 & 2034370 \\
\hline 24 & KCN J10 & 3766 & 2034370 \\
\hline 25 & KCNN3 & 3782 & 3208049 \\
\hline 26 & LRP1 & 4035 & 3253157 \\
\hline 27 & TNF- $\beta$ & 4049 & 4069061 \\
\hline 28 & MEF2D & 4209 & 3986694 \\
\hline 29 & MTHFR & 4524 & 2562562,4231882 \\
\hline 30 & MTR & 4548 & 4231882 \\
\hline 31 & MTRR & 4552 & 4231882 \\
\hline 32 & NGFR & 4804 & 3172930 \\
\hline 33 & NNMT & 4837 & 5056911 \\
\hline 34 & iNOS & 4843 & 3356463 \\
\hline 35 & NOS3 & 4846 & 2704575 \\
\hline 36 & $\mathrm{NOTCH} 4$ & 4855 & 3620438 \\
\hline 37 & OPRM1 & 4988 & 3444536 \\
\hline 38 & PROGINS & 5241 & 4337459 \\
\hline 39 & EDN & 6036 & 2753702 \\
\hline 40 & SCN1A & 6323 & 4706665 \\
\hline 41 & $M C P-1$ & 6347 & 4141767 \\
\hline 42 & SLC6A4 & 6532 & 3476140,3452037 \\
\hline 43 & SOD2 & 6648 & 4283069 \\
\hline 44 & TARBP2 & 6895 & 5541777 \\
\hline 45 & TGFB1 & 7040 & 2704575 \\
\hline 46 & TGFBR2 & 7048 & 3986694 \\
\hline 47 & $T N F$ & 7124 & 4476787,2704575 \\
\hline 48 & $V D R$ & 7421 & 3741896 \\
\hline 40 & VEGF & 7422 & 3356463 \\
\hline 50 & NPFF & 8620 & 5541777 \\
\hline 51 & SLCAA4 & 8671 & 2936614 \\
\hline 52 & FHL5 & 9457 & 5541777 \\
\hline 53 & HEPH & 9843 & 3362572 \\
\hline 54 & $P G C P$ & 10404 & 3986694 \\
\hline 55 & UTS2 & 10911 & 4835397 \\
\hline 56 & VSIG4 & 11326 & 3362572 \\
\hline 57 & SYNE1 & 23345 & 3986694,4196204 \\
\hline 58 & UFL1 & 23376 & 5541777 \\
\hline 59 & NBEA & 26960 & 4394021 \\
\hline 60 & GABRQ & 55879 & 3764027 \\
\hline 61 & PRDM16 & 63976 & 3986694 \\
\hline 62 & TRPM8 & 79054 & 3986694,3253157 \\
\hline 63 & MTDH & 92140 & 3986694,3172930 \\
\hline 64 & ZNF555 & 148254 & 3604878 \\
\hline 65 & MGR1 & 192115 & 1180504 \\
\hline 66 & PHACTR1 & 221692 & 3986694 \\
\hline 67 & $D A O A$ & 267012 & 3837682 \\
\hline 68 & KCNK18 & 338567 & 4706665 \\
\hline 69 & PRRT2 & 401399 & 2704575 \\
\hline 70 & CCR2 & 729230 & 2704575 \\
\hline
\end{tabular}

in the permutation of the corresponding PMIDs of specified genes. 
Table S3 GO function enrichment analysis of gene related to epilepsy

\begin{tabular}{|c|c|c|c|c|c|}
\hline Category & Term & Count & $\%$ & $P$ value & Genes ID \\
\hline GOTERM_MF_DIRECT & $\begin{array}{l}\text { GO:0042803 protein homodimerization } \\
\text { activity }\end{array}$ & 13 & 18.57 & $2.63 \times 10^{-5}$ & $\begin{array}{l}\text { 4209, 7040, 7422, 4843, 6532, } \\
\text { 10404, 729230, 79054, 1813, } \\
2332,6895,23345,348\end{array}$ \\
\hline GOTERM_MF_DIRECT & GO:0050661 NADP binding & 4 & 5.71 & $3.57 \times 10^{-4}$ & $4846,4843,4524,4552$ \\
\hline GOTERM_MF_DIRECT & GO:0010181 FMN binding & 3 & 4.29 & $1.58 \times 10^{-3}$ & $4846,4843,4552$ \\
\hline GOTERM_MF_DIRECT & $\begin{array}{l}\text { GO:0050660 flavin adenine dinucleotide } \\
\text { binding }\end{array}$ & 4 & 5.71 & $2.09 \times 10^{-3}$ & $4846,4843,4524,4552$ \\
\hline GOTERM_MF_DIRECT & GO:0008144 drug binding & 4 & 5.71 & $3.42 \times 10^{-3}$ & $3351,1636,1813,477$ \\
\hline GOTERM_MF_DIRECT & GO:0005125 cytokine activity & 5 & 7.14 & $5.25 \times 10^{-3}$ & $7040,4049,7422,7124,3578$ \\
\hline GOTERM_MF_DIRECT & $\begin{array}{l}\text { GO:0005245 voltage-gated calcium channel } \\
\text { activity }\end{array}$ & 3 & 4.29 & $1.10 \times 10^{-2}$ & $773,4988,2917$ \\
\hline GOTERM_MF_DIRECT & GO:0004517 nitric-oxide synthase activity & 2 & 2.86 & $1.19 \times 10^{-2}$ & 4846,4843 \\
\hline GOTERM_MF_DIRECT & $\begin{array}{l}\text { GO:0031727 CCR2 chemokine receptor } \\
\text { binding }\end{array}$ & 2 & 2.86 & $1.19 \times 10^{-2}$ & 729230,6347 \\
\hline GOTERM_MF_DIRECT & GO:0005216 ion channel activity & 3 & 4.29 & $1.26 \times 10^{-2}$ & $773,6323,79054$ \\
\hline GOTERM_MF_DIRECT & GO:0005102 receptor binding & 6 & 8.56 & $1.30 \times 10^{-2}$ & $\begin{array}{l}8620,4049,5241,10911 \\
4843,6347\end{array}$ \\
\hline GOTERM_MF_DIRECT & $\begin{array}{l}\text { GO:0004971 AMPA glutamate receptor } \\
\text { activity }\end{array}$ & 2 & 2.86 & $1.58 \times 10^{-2}$ & 2892,2890 \\
\hline GOTERM_MF_DIRECT & GO:0034617 tetrahydrobiopterin binding & 2 & 2.86 & $1.58 \times 10^{-2}$ & 4846,4843 \\
\hline GOTERM_MF_DIRECT & $\begin{array}{l}\text { GO:0034714 type III transforming growth } \\
\text { factor beta receptor binding }\end{array}$ & 2 & 2.86 & $1.58 \times 10^{-2}$ & 7040,7048 \\
\hline GOTERM_MF_DIRECT & $\begin{array}{l}\text { GO:0005231 excitatory extracellular ligand- } \\
\text { gated ion channel activity }\end{array}$ & 2 & 2.86 & $1.97 \times 10^{-2}$ & 2892,2890 \\
\hline GOTERM_MF_DIRECT & $\begin{array}{l}\text { GO:0003707 steroid hormone receptor } \\
\text { activity }\end{array}$ & 3 & 4.29 & $2.08 \times 10^{-2}$ & $5241,7421,2099$ \\
\hline GOTERM_MF_DIRECT & GO:0003725 double-stranded RNA binding & 3 & 4.29 & $2.44 \times 10^{-2}$ & $92140,105,6895$ \\
\hline GOTERM_MF_DIRECT & GO:0034618 arginine binding & 2 & 2.86 & $2.76 \times 10^{-2}$ & 4846,4843 \\
\hline GOTERM_MF_DIRECT & GO:0042802 identical protein binding & 8 & 11.43 & $2.86 \times 10^{-2}$ & $\begin{array}{l}\text { 7422, 6648, 7124, 1813, 2332, } \\
\text { 2099, 6895, } 348\end{array}$ \\
\hline GOTERM_MF_DIRECT & GO:0035197 siRNA binding & 2 & 2.86 & $3.13 \times 10^{-2}$ & 2332,6895 \\
\hline GOTERM_MF_DIRECT & GO:0070573 metallodipeptidase activity & 2 & 2.86 & $3.13 \times 10^{-2}$ & 1636,10404 \\
\hline GOTERM_MF_DIRECT & $\begin{array}{l}\text { GO:0034713 type I transforming growth fac- } \\
\text { tor beta receptor binding }\end{array}$ & 2 & 2.86 & $3.52 \times 10^{-2}$ & 7040,7048 \\
\hline GOTERM_MF_DIRECT & $\begin{array}{l}\text { GO:0046982 protein heterodimerization } \\
\text { activity }\end{array}$ & 6 & 8.57 & $3.72 \times 10^{-2}$ & $\begin{array}{l}\text { 4209, 7040, 4855, 7422, 1813, } \\
2332\end{array}$ \\
\hline GOTERM_MF_DIRECT & $\begin{array}{l}\text { GO:0015467 G-protein activated inward rec- } \\
\text { tifier potassium channel activity }\end{array}$ & 2 & 2.86 & $3.90 \times 10^{-2}$ & 3765,3766 \\
\hline GOTERM_MF_DIRECT & GO:0008066 glutamate receptor activity & 2 & 2.86 & $4.28 \times 10^{-2}$ & 2917,2890 \\
\hline GOTERM_MF_DIRECT & GO:0019899 enzyme binding & 5 & 7.14 & $4.32 \times 10^{-2}$ & $\begin{array}{l}7040,5241,2099,6895 \\
267012\end{array}$ \\
\hline GOTERM_MF_DIRECT & $\begin{array}{l}\text { GO:0004970 ionotropic glutamate receptor } \\
\text { activity }\end{array}$ & 2 & 2.86 & $5.79 \times 10^{-2}$ & 2892,2890 \\
\hline GOTERM_MF_DIRECT & GO:0035198 miRNA binding & 2 & 2.86 & $6.17 \times 10^{-2}$ & 2332,6895 \\
\hline GOTERM_MF_DIRECT & GO:0004180 carboxypeptidase activity & 2 & 2.86 & $6.54 \times 10^{-2}$ & 1636,10404 \\
\hline GOTERM_MF_DIRECT & $\begin{array}{l}\text { GO:0005234 extracellular-glutamate-gated } \\
\text { ion channel activity }\end{array}$ & 2 & 2.86 & $6.91 \times 10^{-2}$ & 2892,2890 \\
\hline GOTERM_MF_DIRECT & GO:0004890 GABA-A receptor activity & 2 & 2.86 & $7.28 \times 10^{-2}$ & 2556,55879 \\
\hline GOTERM_MF_DIRECT & $\begin{array}{l}\text { GO:0005242 inward rectifier potassium } \\
\text { channel activity }\end{array}$ & 2 & 2.86 & $7.65 \times 10^{-2}$ & 3765,3766 \\
\hline GOTERM_MF_DIRECT & $\begin{array}{l}\text { GO:0033613 activating transcription factor } \\
\text { binding }\end{array}$ & 2 & 2.86 & $8.38 \times 10^{-2}$ & 4209,63976 \\
\hline GOTERM_MF_DIRECT & $\begin{array}{l}\text { GO:0030594 neurotransmitter receptor } \\
\text { activity }\end{array}$ & 2 & 2.86 & $9.83 \times 10^{-2}$ & 3351,3363 \\
\hline GOTERM_MF_DIRECT & GO:0003779 actin binding & 4 & 5.71 & $9.84 \times 10^{-2}$ & $221692,1636,2638,23345$ \\
\hline
\end{tabular}




\begin{tabular}{|c|c|c|c|c|c|}
\hline $\begin{array}{l}\text { Category } \\
\text { GTERM ME DIRECT }\end{array}$ & Term & Count & 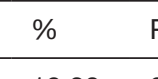 & Pvalue & $\begin{array}{l}\text { Genes ID } \\
\end{array}$ \\
\hline GOTERM_MF_DREET & $\begin{array}{l}\text { G0:0042802-identical protein } \\
\text { binding }\end{array}$ & ${ }^{33}$ & $19.30=2$ & $2.27 \times 10^{12}$ & 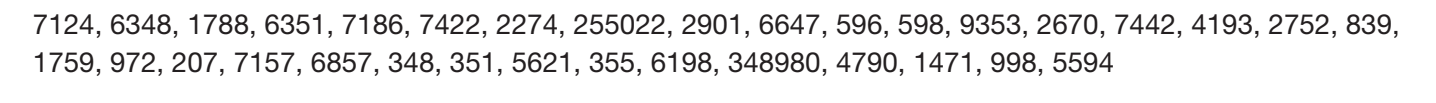 \\
\hline GOTERM_MF_DIRECT & 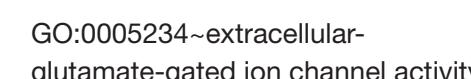 & & 5.26 & $3.27 \times 10^{12}$ & $2901,2897,2902,2898$, , 2003, 2904, 2891, 2890, 2900 \\
\hline GOTERM_MF_DIRECT & $\begin{array}{l}\text { Ga:0004970-inontropic glutamate } \\
\text { recepto activition }\end{array}$ & & 4.09 & $4.13 \times 10^{\circ}$ & 2897, , 2902, 2898, 2903, 2891, 2890, 2900 \\
\hline GOTERM_MF_DIRECT & $\begin{array}{l}\text { 60:0000066-glutamate recepptor } \\
\text { activy }\end{array}$ & 6 & 3.51 & $4.05 \times 10^{8}$ & $2915,2911,2913,2917,2890,2911$ \\
\hline GOTERM_MF_DIRECT & 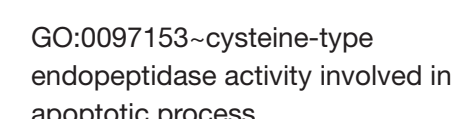 & ${ }^{6}$ & 3.51 & $1.11 \times 10^{7}$ & $842,840,837,839,834,836$ \\
\hline GOTERM_MF_DIRECT & G0:0005515-protetin binding & 119 & 69.59 & $1.07 \times 10^{6}$ & 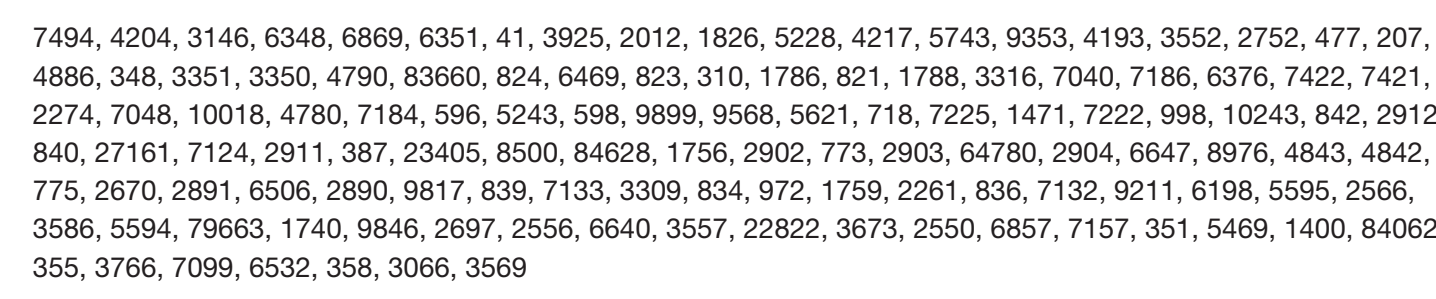 \\
\hline GOTERM-MF_DIEECT & $\begin{array}{l}\text { G0:0050999-nititic-oxide synthase } \\
\text { binding }\end{array}$ & 5 & $2.92 \varepsilon$ & $8.77 \times 10^{6}$ & $1756,6532,6640,1759,972$ \\
\hline GOTERM_MF_DIRECT & $\begin{array}{l}\text { G0:0015277-kainate selective } \\
\text { glutamate receptor activity }\end{array}$ & 4 & $2.34=$ & $9.54 \times 10^{6}$ & $2901,2897,2898,2900$ \\
\hline $\begin{array}{l}\text { GOTERM_MF_DIEET } \\
\text { GOTERMM MFDIRECT }\end{array}$ & $\begin{array}{l}\text { GQ:0005125 - cytokine activity } \\
\text { G0:0005262-calcium channel }\end{array}$ & 11 & $\begin{array}{ll}6.43 \\
409\end{array}$ & $1.07 \times 10^{5}$ & $\begin{array}{l}7040,6351,7422,3446,3084,7124,3553,3552,3586,3569,3557 \\
2902,773,2903,7225,7442,24145,7222\end{array}$ \\
\hline GOTERM MF DIRECT & $\begin{array}{l}\text { activity } \\
\text { G:0016595-glutamate binding }\end{array}$ & 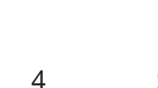 & ( & 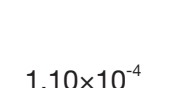 & \\
\hline GOTERM_MF_DIRECT & 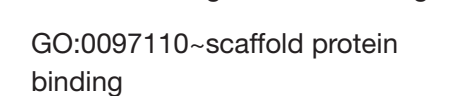 & 6 & 3.51 & $1.10 \times 10^{4}$ & $8912,2697,4842,5595,4193,244145$ \\
\hline GOTERM_MF_DIRECT & 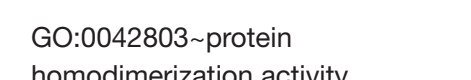 & 20 & 11.70 & $1.23 \times 10^{4}$ & 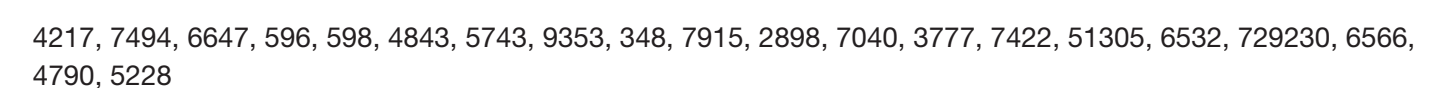 \\
\hline $\begin{array}{l}\text { GOTERM_MF_DIRECT } \\
\text { GOTERM_MF_DIRECT }\end{array}$ & $\begin{array}{l}\text { G0:0030165-PDZ domain binding } \\
\text { G0:0004197-cystane-type }\end{array}$ & $\begin{array}{l}7 \\
6\end{array}$ & $\begin{array}{ll}4.09 & 2 \\
3.51 & 3\end{array}$ & $\begin{array}{l}2.16 \times 10^{4} \\
3.49 \times 10^{4}\end{array}$ & $\begin{array}{l}2901,2697,2898,6198,2917,2890,6640 \\
842,840,837,839,834,836\end{array}$ \\
\hline $\begin{array}{l}\text { GOTERM_MF_DIRECT } \\
\text { GOTERM_MF_DIRECT }\end{array}$ & $\begin{array}{l}\text { G0:0002020-protease binding } \\
\text { G0:0003135-mitosen-activated }\end{array}$ & $\begin{array}{l}7 \\
4\end{array}$ & $\begin{array}{ll}4.09 & 5 \\
2.34 & \vdots\end{array}$ & $5.16 \times 10^{4}$ & $\begin{array}{l}7494,596,7124,147,244145,7157,836 \\
71766,7848,998,5594\end{array}$ \\
\hline GOTERM_MF_DIRECT & 60:0005516-calmodulin binding & 9 & 5.26 & $6.16 \times 10^{4}$ & 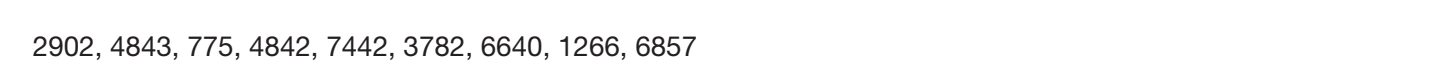 \\
\hline GOTERM_MF_DIRECT & G0:0005216-ion channel activity & 5 & 2.92 & $8.63 \times 10^{4}$ & $6326,773,3777,6323,7442$ \\
\hline GOTERM_MF_DIRECT & 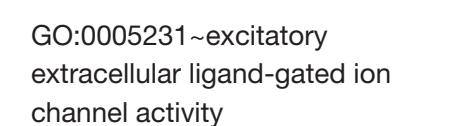 & 3 & $1.75 \mathrm{~s}$ & $9.65 \times 10^{4}$ & $2891,7442,2890$ \\
\hline GOTERM_MF_DIRECT & $\begin{array}{l}\text { Ga:00050088-Ras guanyl-nuleotid. } \\
\text { exchange factor activit }\end{array}$ & e 7 & 4.09 & $1.02 \times 10^{3}$ & $9365,2902,2903,2904,3084,5923,2261$ \\
\hline GOTERM_MF_DIRECT & $\begin{array}{l}\text { 60:0000134-transcription factor } \\
\text { bindiog }\end{array}$ & 10 & 5.85 & $2.9 \times 10^{3}$ & $596,4204,2274,3146,3066,9817,4790,7157,5594,54499$ \\
\hline GOTERM_MF_DIRECT & 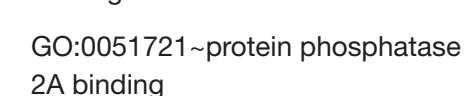 & 4 & $2.34=2$ & $2.38 \times 10^{3}$ & $6198,596,207,7157$ \\
\hline GOTERM_MF_DIRECT & 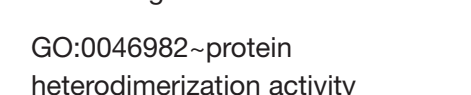 & 13 & 7.60 & $2.43 \times 10^{3}$ & $824,7494,3777,7040,3673,596,7422,598,51305,4790,24145,5228,71157$ \\
\hline $\begin{array}{l}\text { GOTERMMMF_DIEECT } \\
\text { GOTERM_MF_DIEECT }\end{array}$ & $\begin{array}{l}\text { 60:0035197-sirNA binding } \\
\text { 60:0004972-NMDA Alutamate }\end{array}$ & $\begin{array}{l}3 \\
3\end{array}$ & $\begin{array}{ll}1.75 & 2 \\
1.75 & 2\end{array}$ & $\begin{array}{l}2.65 \times 10^{3} \\
2.55 \times 10^{9}\end{array}$ & $\begin{array}{l}4204,27161,23405 \\
2902,2003,2004\end{array}$ \\
\hline $\begin{array}{l}\text { GOTERM_MF_DIRECT } \\
\text { GOTERM_MF_DIFECT }\end{array}$ & $\begin{array}{l}\text { 60:0005102--receptor binding } \\
\text { 60:00347-13-typel transtorming }\end{array}$ & $\begin{array}{l}11 \\
3\end{array}$ & $\begin{array}{ll}6.43 & 2 \\
1.75 & 3\end{array}$ & $\begin{array}{l}2.86 \times 10^{3} \\
3.39 \times 10^{9}\end{array}$ & $\begin{array}{l}2697,8862,2922,9211,718,6376,3084,4843,6347,24145,351 \\
83891,704,7048\end{array}$ \\
\hline GOTERM_MF_DIRECT & G0:0001948-glycoprotetin binding & 5 & 2.92 & $4.00 \times 10^{3} \mathrm{~s}=0$ & $7040,6469,2670,3309,821$ \\
\hline $\begin{array}{l}\text { GOTERM_MF_DIRECT } \\
\text { GOTERM_MF_DIRECT }\end{array}$ & $\begin{array}{l}\text { GQ:0051378-serotonin binding } \\
\text { G0:0005230-extracelluar Iigand- }\end{array}$ & $\begin{array}{l}3 \\
4\end{array}$ & $\begin{array}{ll}1.75 \\
2.34\end{array}$ & $\begin{array}{l}4.20 \times 10^{3} \\
4.24 \times 10^{3}\end{array}$ & $\begin{array}{l}3356,3351,3350 \\
2562,7442,2556,2566\end{array}$ \\
\hline GOTERM_MF_DIRECT & GQ:0015276-1igand-gated ion & 4 & 2.34 & $5.43 \times 10^{3}$ & $2901,2897,2898,2900$ \\
\hline $\begin{array}{l}\text { GOTERMM-MFDIRECT } \\
\text { GOTERMM-MF_DIECT }\end{array}$ & $\begin{array}{l}\text { G0:0008083-growth factor activity } \\
\text { G0:0005267 potassium channel }\end{array}$ & 7 & $\begin{array}{ccc}4.09 & 5 \\
2.34 & \vdots\end{array}$ & $\begin{array}{l}5.67 \times 10^{3} \\
5.87 \times 10^{3}\end{array}$ & $\begin{array}{l}7040,7422,3084,627,3586,3569,5228 \\
3777,348880,51305,358\end{array}$ \\
\hline GOTERM_MF_DIRECT & 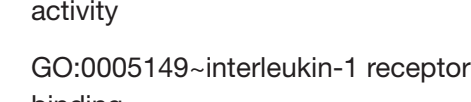 & 3 & 1.75 & $7.15 \times 10^{3}$ & $3553,3552,3557$ \\
\hline GOTERM_MF_DIRECT & $\begin{array}{l}\text { 60:00052455-voltage-gated calciun } \\
\text { chamane acivt }\end{array}$ & 4 & 2.34 & $7.30 \times 10^{3}$ & $773,2917,775,255022$ \\
\hline $\begin{array}{l}\text { GOTERMM-MF_DIRECT } \\
\text { GOTERMM-MF_DRECT }\end{array}$ & $\begin{array}{l}\text { G0:00551087-chaperone binding } \\
\text { G0:0050750-low-density }\end{array}$ & $\begin{array}{l}5 \\
3\end{array}$ & $\begin{array}{ll}2.92 & \varepsilon \\
1.75 & 1\end{array}$ & $\begin{array}{l}8.69 \times 10^{3} \\
1.08 \times 10^{2}\end{array}$ & $\begin{array}{l}6647,3309,477,7157,5621 \\
7184,6857,348\end{array}$ \\
\hline $\begin{array}{l}\text { GOTERMMMF_DIRECT } \\
\text { GOTERMM-MF_IIECTT }\end{array}$ & $\begin{array}{l}\text { Ga:0000009-chemokokne activity } \\
\text { G0:00202557-transmembrane }\end{array}$ & 4 & $\begin{array}{l}2.34 \\
2.34 \\
2.34\end{array}$ & $\begin{array}{l}1.28 \times 10^{2} \\
1.28 \times 10^{2}\end{array}$ & 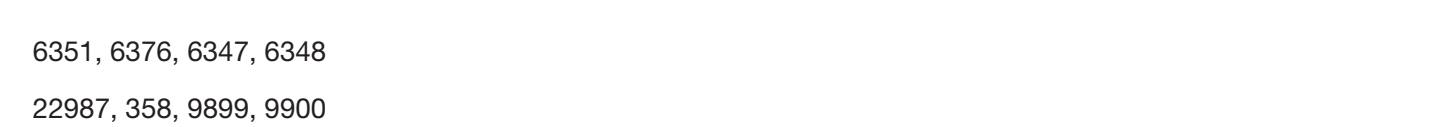 \\
\hline $\begin{array}{l}\text { GOTERMMMF_DIRECT } \\
\text { GOOEMM MF FIDECT }\end{array}$ & 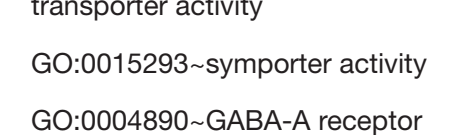 & $\begin{array}{l}4 \\
3\end{array}$ & $\begin{array}{l}2.34 \\
1.75 \\
1.75\end{array}$ & $\begin{array}{l}1.42 \times 10^{2} \\
.5 \times 10^{2}\end{array}$ & $\begin{array}{l}9194,6506,6566,6507 \\
25652562566\end{array}$ \\
\hline 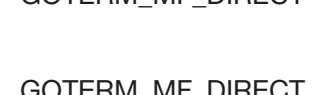 & 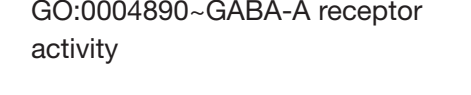 & & & & $2562,2556,2566$ \\
\hline GOTERM_MF_DIEECT & $\begin{array}{l}\text { GG:00050242-8-ovtage-gated sodium } \\
\text { channel activity }\end{array}$ & 3 & 1.75 & $1.66 \times 10^{2}$ & 6326, 348988, ,6323 \\
\hline $\begin{array}{l}\text { GOTERMMMF-DIEECT } \\
\text { GTREM MFIDECT }\end{array}$ & GQ:0005507 copper ion binding & 4 & 2.34 & $1.83 \times 10^{2}$ & $6647,3552,7157,5621$ \\
\hline $\begin{array}{l}\text { GOOTRR_MF_DRRET } \\
\text { GOTERM_MF_DRECT }\end{array}$ & 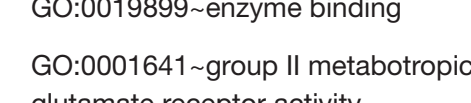 & 2 & $\begin{array}{l}5.6 \\
1.17 \\
1.17\end{array}$ & $\begin{array}{l}1.85 \times 10^{2} \\
1.98 \times 0^{2}\end{array}$ & 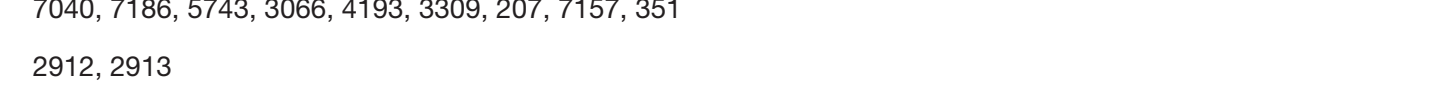 \\
\hline GOTERMMF-DIRECT & GO:0017022 -myosin binding & 3 & 1.75 & $2.00 \times 10^{2}$ & ${ }_{1756,387,6532}$ \\
\hline GOTERMMMF_DIRECT & GO:0005178-integrin binding & 5 & 2.92 & $2.08 \times 10^{2}$ & $3673,6376,3084,2670,310$ \\
\hline GOTERMMMF_DIRECT & GO:0003779 actin binding & 8 & 4.68 z & $2.14 \times 10^{2}$ & $1756,64780,8976,2638,7225,6640,83660,12666$ \\
\hline $\begin{array}{l}\text { GOTERM_MF_DIRECT } \\
\text { GOTERM_MF_DIRECT }\end{array}$ & $\begin{array}{l}\text { GQ:0008201-heparin binding } \\
\text { GQ:0005031-tumor necrosis factor }\end{array}$ & $\begin{array}{l}6 \\
-3\end{array}$ & $\begin{array}{ll}3.51 \\
1.75 \\
1.75\end{array}$ & $\begin{array}{l}2.20 \times 10^{2} \\
2.35 \times 10^{2}\end{array}$ & $\begin{array}{l}7422,9353,6347,5228,348,351 \\
355,7133,7132\end{array}$ \\
\hline GOTERM_MF_DIRECT & GQ:0031625- ubiquitin protein & 8 & 4.68 & $2.48 \times 10^{2}$ & $7494,2898,7186,599,4193,33099,7133,7157$ \\
\hline GOTERM_MF_DIRECT & GO:0019903-protein phosphatase & 4 & 2.34 & $2.49 \times 10^{2}$ & $4217,7186,7184,7157$ \\
\hline GOTERM_MF_DIRECT & $\begin{array}{l}\text { binding } \\
\text { G0:0001047 core promoter bindin }\end{array}$ & 94 & 2.34 & $2.59 \times 10^{2}$ & 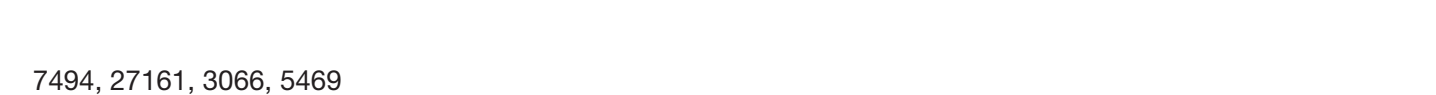 \\
\hline GOTERM_MF_DIRECT & 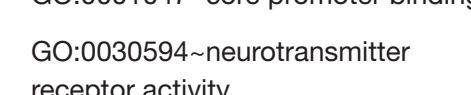 & 3 & 1.75 & $2.74 \times 10^{2}$ & $3356,3351,3350$ \\
\hline GOTERM_MF_DIRECT & 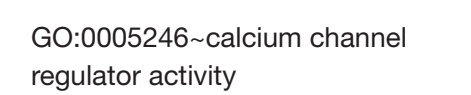 & 3 & 1.75 & $2.94 \times 10^{2}$ & $2912,2913,2917$ \\
\hline GOTERM_MF_DIRECT & $\begin{array}{l}\text { 60:00042056-chemoatrtractant } \\
\text { acavitit }\end{array}$ & 3 & 1.75 & $2.94 \times 10^{2}$ & $7422,3446,6348$ \\
\hline GOTERM_MF_DIRECT & $\begin{array}{l}\text { Go:0004517-nitici-oxide synthase } \\
\text { activy }\end{array}$ & 2 & 1.172 & $2.96 \times 10^{2}$ & 4843,4842 \\
\hline GOTERM_MF_DIRECT & 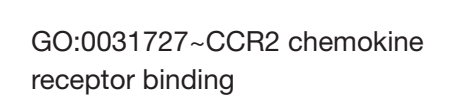 & 2 & $1.17 \quad 2$ & $2.96 \times 10^{2}$ & 729230,6347 \\
\hline GOTERM_MF_DIRECT & 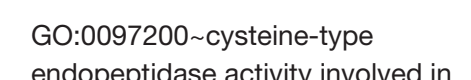 & 2 & $1.17 \quad 2$ & $2.96 \times 10^{2}$ & 840,836 \\
\hline GOTERM_MF_DIRECT & 60:0015252-seretonin & 2 & $1.172^{2}$ & $2.96 \times 10^{2}$ & 65332,6571 \\
\hline GOTERM_MF_DIRECT & GQ:0004965-G-protetin coupled & 2 & $1.17=2$ & $2.96 \times 10^{2}$ & 2550,9568 \\
\hline GOTERM_MF_DIRECT & G0:0004993-G-protetin coupled & 3 & $1.75:$ & $3.14 \times 10^{2}$ & 3356, 3351, ,350 \\
\hline GOTERM_MF_DIRECT & GQ:00004712-protein serine/ & 3 & 1.75 & $3.35 \times 10^{2}$ & $6198,5649,207$ \\
\hline $\begin{array}{l}\text { GOTERMMMF_DRECT } \\
\text { GOTERM MF DRECT }\end{array}$ & G0:0019901 - protteri Kinase bindine & 9 & 5.26 & $3.47 \times 10^{2}$ & 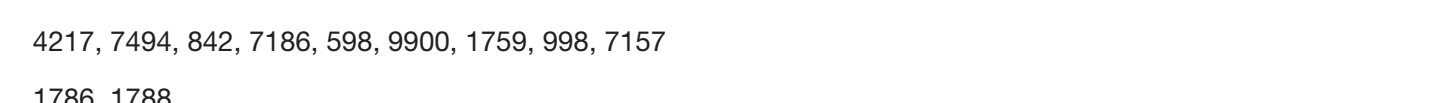 \\
\hline GOTERM ME DIRECT & 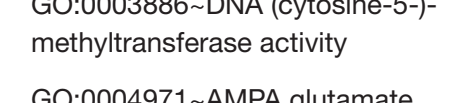 & , & $117=$ & 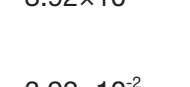 & T/766, /1788 \\
\hline 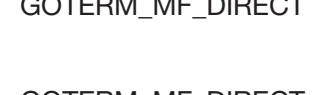 & 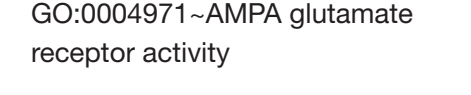 & 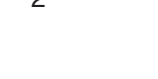 & (1... & 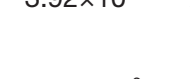 & 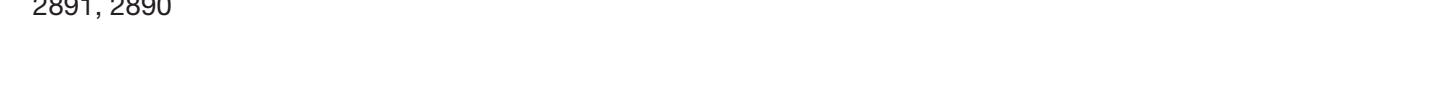 \\
\hline GOTERM_MF_DIRECT & $\begin{array}{l}\text { G0:003034617-tetrahydrobiopterin } \\
\text { binding }\end{array}$ & ${ }^{2}$ & 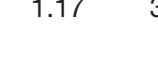 & $3.92 \times 10^{2}$ & 4843,4842 \\
\hline GOTERM_MF_DIRECT & 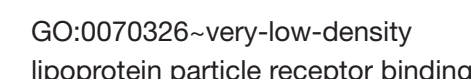 & 2 & $1.17=3$ & $3.92 \times 10^{2}$ & 5649,348 \\
\hline GOTERM_MF_DIRECT & 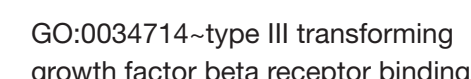 & 2 & $1.17=$ & $3.92 \times 10^{2}$ & 7040,7048 \\
\hline $\begin{array}{l}\text { GOTERMMMF_DIRECT } \\
\text { GOTERM_MF_DIEECT }\end{array}$ & $\begin{array}{l}\text { G0:0051434-BH3 domain binding } \\
\text { G0:0005172-vascular endothelial }\end{array}$ & $\begin{array}{l}2 \\
2\end{array}$ & $\begin{array}{ll}1.17 \\
1.17 & 3 \\
3 & 3\end{array}$ & $\begin{array}{l}3.92 \times 10^{2} \\
3.92 \times 10^{2}\end{array}$ & $\begin{array}{l}596,598 \\
7422,5228\end{array}$ \\
\hline $\begin{array}{l}\text { GOTERMMMF_DIRECT } \\
\text { GOTRM_MF_DIRECT }\end{array}$ & $\begin{array}{l}\text { G0:0001540-beta-amyloid binding } \\
\text { G0:005061-NADP binding }\end{array}$ & $\begin{array}{l}3 \\
3\end{array}$ & $\begin{array}{l}1.75 \\
1.75\end{array}$ & $\begin{array}{l}4.49 \times 10^{2} \\
4.73 \times 10^{2}\end{array}$ & $\begin{array}{l}1471,972,348 \\
4843,452,4842\end{array}$ \\
\hline GOTERM_MF_DIRECT & 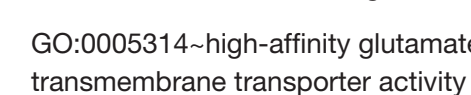 & $=2$ & $1.17 \quad 4$ & $4.88 \times 10^{2}$ & 6500,6507 \\
\hline GOTERMMMF_DIEECT & 60:0009008-DNA- & ${ }^{2}$ & 1.17 & $4.88 \times 10^{2}$ & 1786, 1788 \\
\hline GOTERMMMFDIRECT & 60:0005999 vitamin D binding & ${ }^{2}$ & 1.17 & $4.88 \times 10^{2}$ & 9365,2638 \\
\hline GOTERMMMF_DIRECT & $\begin{array}{l}\text { Go:00044871-ignal transoucer } \\
\text { activity }\end{array}$ & 6 & & & $9365,2697,355$ \\
\hline GOTERM_MF_DIRECT & 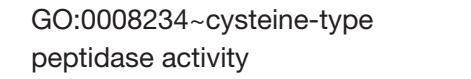 & 3 & 1.75 & $5.48 \times 10^{2}$ & $824,840,839$ \\
\hline GOTERM_MF_DIRECT & $\begin{array}{l}\text { G0:00032403-protetin complex } \\
\text { binding }\end{array}$ & ${ }^{6}$ & 3.51 & $5.52 \times 10^{2}$ & $3356,3673,7186,4524,1759,836$ \\
\hline GOTERM_MF_DIRECT & 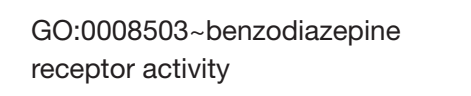 & 2 & 1.17 & $5.83 \times 10^{2}$ & 2556,2566 \\
\hline GOTERM_MF_DIRECT & $\begin{array}{l}\text { Go:0005372-water transmembra } \\
\text { transoorte a ativi }\end{array}$ & 2 & $1.17 \mathrm{~s}$ & $5.83 \times 10^{2}$ & 358,361 \\
\hline GOTERM_MF_DIRECT & G0:0043237_/laminin-1 binding & ${ }^{2}$ & $1.17 \mathrm{~s}$ & $5.83 \times 10^{2}$ & 6469,9353 \\
\hline $\begin{array}{l}\text { GOTERM_MF_DIRECT } \\
\text { GOTERM_MF_DIRECT }\end{array}$ & $\begin{array}{l}\text { G0:0008233-peppitiase activity } \\
\text { G0:0008504-monoamine }\end{array}$ & 4 & $\begin{array}{l}2.34 \\
1.17 \\
1.8\end{array}$ & $\begin{array}{l}6.08 \times 10^{2} \\
6.76 \times 10^{2}\end{array}$ & $\begin{array}{l}842,6469,836,351 \\
6532,6571\end{array}$ \\
\hline $\begin{array}{l}\text { GOTERMMMFDDRECT } \\
\text { GOTERMM MFDECT }\end{array}$ & G0:0034618-arganine binding & 2 & $\begin{array}{ll}1.17 \\
1.7\end{array}$ & $\begin{array}{l}6.76 \times 10^{2} \\
676610^{2}\end{array}$ & $\begin{array}{l}4843,4842 \\
6351,6348\end{array}$ \\
\hline GOTERM_MF_DIRECT & $\begin{array}{l}\text { receptor binding } \\
\text { G0:0031730_CCR5 chemokine }\end{array}$ & 2 & $1.17 \quad 7$ & $7.69 \times 10^{2}$ & ${ }_{6351,6348}$ \\
\hline GOT & $\begin{array}{l}\text { receppotob bining } \\
\text { G0:002805-actinin binding }\end{array}$ & 2 & 1.17 & $9.52 \times 10^{2}$ & 7225,4790 \\
\hline GOTERM_MF_DIRECT & 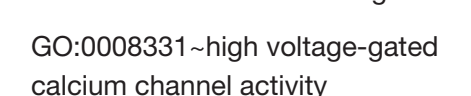 & 2 & 1.17 & $9.52 \times 10^{2}$ & 773,775 \\
\hline GOTERM_MF_DIRECT & 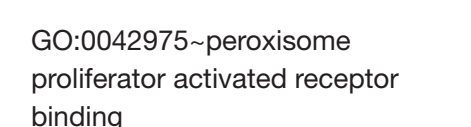 & 2 & $1.17 \mathrm{~s}$ & $9.52 \times 10^{2}$ & 4193,5649 \\
\hline
\end{tabular}


Table S5 Signaling pathway enrichment analysis related to epilepsy

\begin{tabular}{|c|c|c|c|c|}
\hline \#Pathway ID & Pathway description & $\begin{array}{l}\text { Observed } \\
\text { gene count }\end{array}$ & $P$ value & Matching genes \\
\hline 670 & One carbon pool by folate & 2 & $2.10 \times 10^{-2}$ & MTHFR, MTR \\
\hline 4020 & Calcium signaling pathway & 5 & $6.21 \times 10^{-3}$ & CACNA1A, EDNRB, HTR7, NOS2, NOS3 \\
\hline 4022 & cGMP-PKG signaling pathway & 4 & $2.20 \times 10^{-2}$ & ATP1A2, EDNRB, MEF2D, NOS3 \\
\hline 4060 & $\begin{array}{l}\text { Cytokine-cytokine receptor } \\
\text { interaction }\end{array}$ & 9 & $2.38 \times 10^{-5}$ & $\begin{array}{l}\text { CCL2, CCR2, IL9, LTA, NGFR, TGFB1, TGFBR2, TNF, } \\
\text { VEGFA }\end{array}$ \\
\hline 4066 & HIF-1 signaling pathway & 3 & $4.75 \times 10^{-2}$ & NOS2, NOS3, VEGFA \\
\hline 4080 & $\begin{array}{l}\text { Neuroactive ligand-receptor } \\
\text { interaction }\end{array}$ & 11 & $5.18 \times 10^{-7}$ & $\begin{array}{l}\text { DRD2, EDNRB, GABRA3, GABRQ, GRIA1, GRIA3, } \\
\text { GRM7, HCRTR1, HTR1B, HTR7, OPRM1 }\end{array}$ \\
\hline 4350 & TGF-beta signaling pathway & 3 & $2.40 \times 10^{-2}$ & TGFB1, TGFBR2, TNF \\
\hline 4668 & TNF signaling pathway & 3 & $4.86 \times 10^{-2}$ & $C C L 2, L T A, T N F$ \\
\hline 4713 & Circadian entrainment & 3 & $3.37 \times 10^{-2}$ & GRIA1, GRIA3, KCNJ9 \\
\hline 4723 & $\begin{array}{l}\text { Retrograde endocannabinoid } \\
\text { signaling }\end{array}$ & 6 & $5.39 \times 10^{-5}$ & CACNA1A, GABRA3, GABRQ, GRIA1, GRIA3, KCNJ9 \\
\hline 4724 & Glutamatergic synapse & 4 & $8.51 \times 10^{-3}$ & CACNA1A, GRIA1, GRIA3, GRM7 \\
\hline 4726 & Serotonergic synapse & 5 & $1.03 \times 10^{-3}$ & CACNA1A, HTR1B, HTR7, KCNJ9, SLC6A4 \\
\hline 4727 & GABAergic synapse & 3 & $2.87 \times 10^{-2}$ & CACNA1A, GABRA3, GABRQ \\
\hline 4728 & Dopaminergic synapse & 6 & $2.01 \times 10^{-4}$ & CACNA1A, DRD2, GRIA1, GRIA3, KCNJ9, SCN1A \\
\hline 4730 & Long-term depression & 3 & $1.41 \times 10^{-2}$ & CACNA1A, GRIA1, GRIA3 \\
\hline 4915 & Estrogen signaling pathway & 4 & $5.99 \times 10^{-3}$ & ESR1, KCNJ9, NOS3, OPRM1 \\
\hline 4940 & Type I diabetes mellitus & 3 & $6.21 \times 10^{-3}$ & HLA-DRB1, LTA, TNF \\
\hline 4961 & $\begin{array}{l}\text { Endocrine and other factor-regulated } \\
\text { calcium reabsorption }\end{array}$ & 3 & $8.51 \times 10^{-3}$ & ATP1A2, ESR1, VDR \\
\hline 4964 & $\begin{array}{l}\text { Proximal tubule bicarbonate } \\
\text { reclamation }\end{array}$ & 2 & $2.10 \times 10^{-2}$ & ATP1A2, SLC4A4 \\
\hline 4978 & Mineral absorption & 3 & $9.06 \times 10^{-3}$ & ATP1A2, HEPH, VDR \\
\hline 5032 & Morphine addiction & 5 & $4.95 \times 10^{-4}$ & CACNA1A, GABRA3, GABRQ, KCNJ9, OPRM1 \\
\hline 5033 & Nicotine addiction & 5 & $2.38 \times 10^{-5}$ & CACNA1A, GABRA3, GABRQ, GRIA1, GRIA3 \\
\hline 5140 & Leishmaniasis & 4 & $2.40 \times 10^{-3}$ & HLA-DRB1, NOS2, TGFB1, TNF \\
\hline 5142 & $\begin{array}{l}\text { Chagas disease (American } \\
\text { trypanosomiasis) }\end{array}$ & 5 & $6.21 \times 10^{-4}$ & CCL2, NOS2, TGFB1, TGFBR2, TNF \\
\hline 5144 & Malaria & 4 & $6.21 \times 10^{-4}$ & CCL2, LRP1, TGFB1, TNF \\
\hline 5145 & Toxoplasmosis & 4 & $8.93 \times 10^{-3}$ & HLA-DRB1, NOS2, TGFB1, TNF \\
\hline 5146 & Amoebiasis & 3 & $4.75 \times 10^{-2}$ & NOS2, TGFB1, TNF \\
\hline 5152 & Tuberculosis & 5 & $5.99 \times 10^{-3}$ & HLA-DRB1, NOS2, TGFB1, TNF, VDR \\
\hline 5166 & HTLV-I infection & 5 & $1.99 \times 10^{-2}$ & HLA-DRB1, LTA, TGFB1, TGFBR2, TNF \\
\hline 5168 & Herpes simplex infection & 4 & $2.87 \times 10^{-2}$ & CCL2, HLA-DRB1, LTA, TNF \\
\hline 5212 & Pancreatic cancer & 3 & $1.56 \times 10^{-2}$ & TGFB1, TGFBR2, VEGFA \\
\hline 5310 & Asthma & 3 & $2.83 \times 10^{-3}$ & HLA-DRB1, IL9, TNF \\
\hline 5321 & Inflammatory bowel disease (IBD) & 3 & $1.57 \times 10^{-2}$ & HLA-DRB1, TGFB1, TNF \\
\hline 5323 & Rheumatoid arthritis & 6 & $3.27 \times 10^{-5}$ & CCL2, CTLA4, HLA-DRB1, TGFB1, TNF, VEGFA \\
\hline 5330 & Allograft rejection & 2 & $4.95 \times 10^{-2}$ & $H L A-D R B 1, T N F$ \\
\hline
\end{tabular}




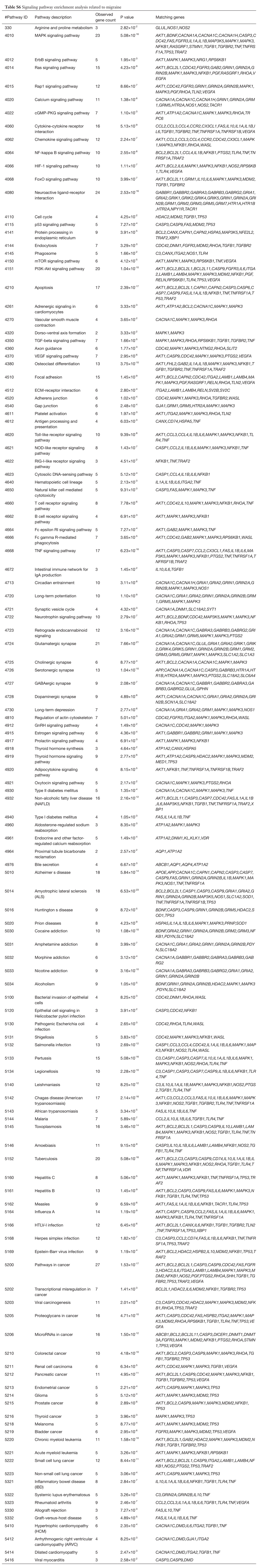




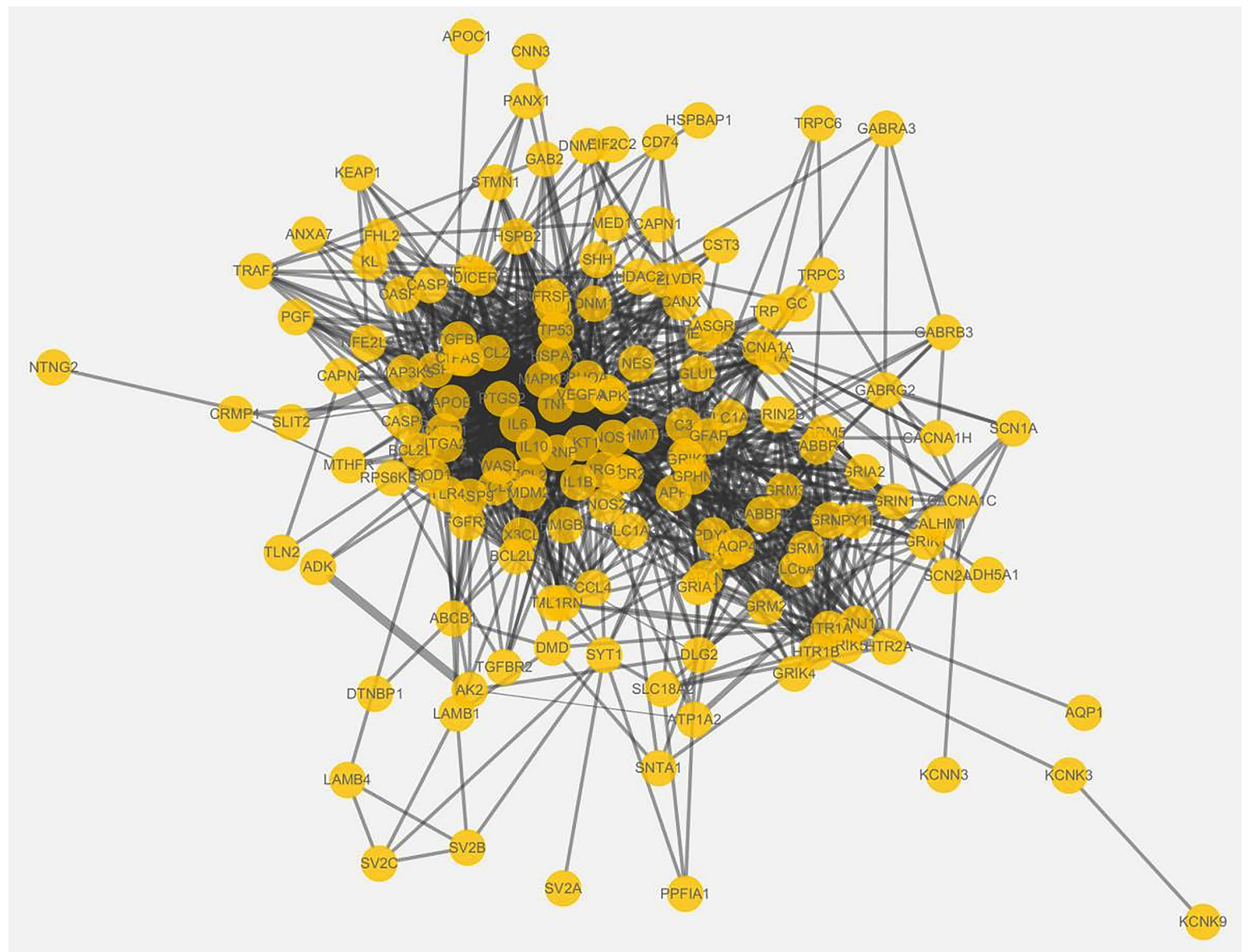

Figure S1 A protein-protein interactions network mapping the epilepsy-related genes. 


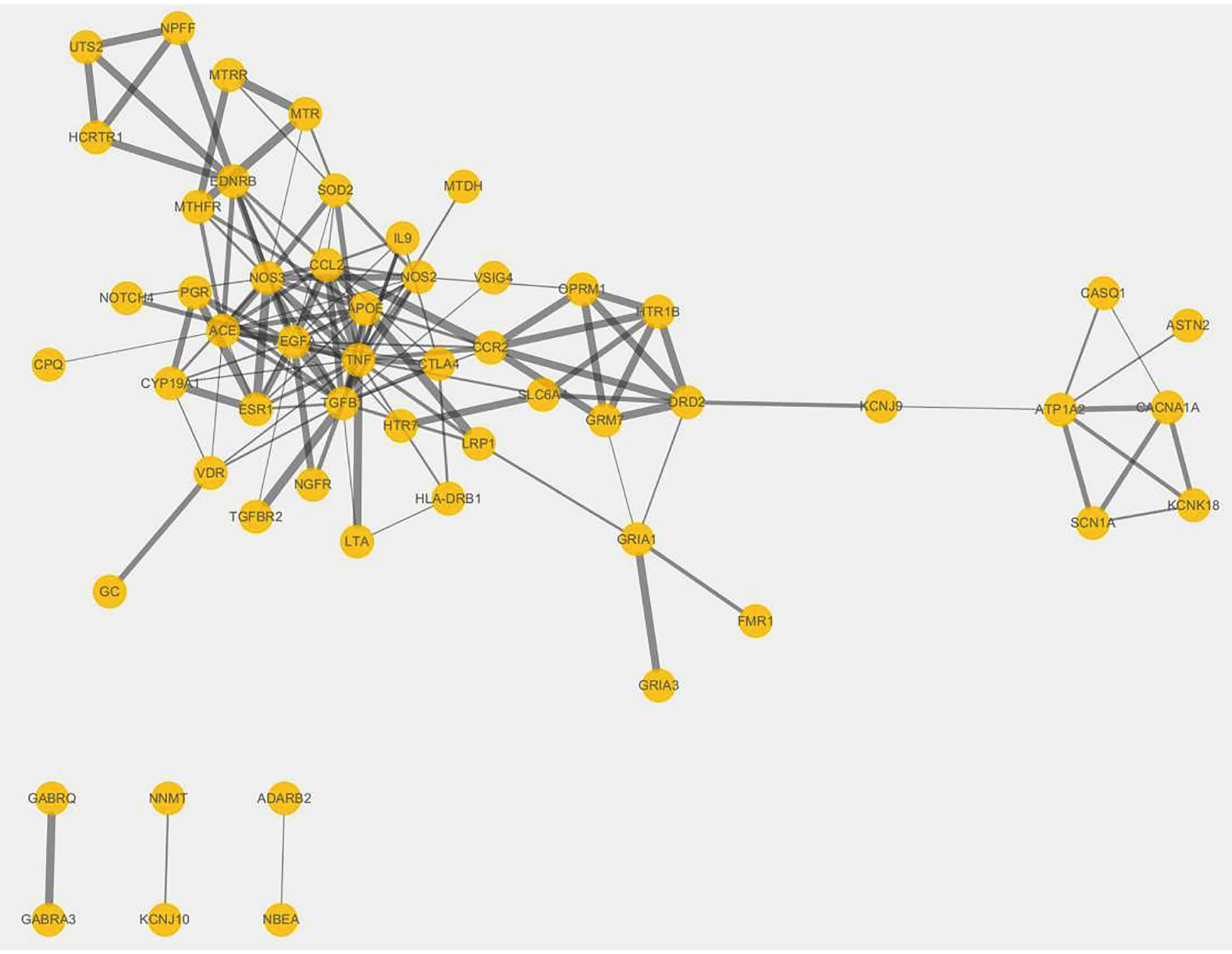

Figure S2 A protein-protein interactions network mapping the migraine-related genes. 